\title{
Blue mussel (Mytilus spp.) cultivation in mesohaline eutrophied inner coastal waters: mitigation potential, threats and cost effectiveness
}

\author{
Lukas Ritzenhofen ${ }^{\text {Corresp., } 1,2}{ }^{\text {, Anna-Lucia Buer }}{ }^{1}$, Greta Gyraite ${ }^{1,2}{ }^{2}$, Sven Dahlke ${ }^{3}$, Annemarie Klemmstein ${ }^{1}$, Gerald \\ Schernewski ${ }^{1,2}$ \\ ${ }^{1}$ The Leibniz Institute for Baltic Sea Research, Warnemünde, Rostock, Germany \\ 2 Marine Research Institute, Klaipeda University, Klaipeda, Lithuania \\ 3 Biological Station Hiddensee, University of Greifswald, Greifswald, Germany \\ Corresponding Author: Lukas Ritzenhofen \\ Email address: lukas.ritzenhofen@io-warnemuende.de
}

The EU-water framework directive (WFD) focuses on nutrient reductions to return coastal waters to the good ecological status.As of today, many coastal waters have reached a steady state of insufficient water quality due to continuous external nutrient inputs and internal loadings. This study focuses first on the current environmental status of mesohaline inner coastal waters to illustrate their needs of internal measures to reach demanded nutrient reductions and secondly, if mussel cultivation can be a suitable strategy to improve water quality. Therefore, nitrogen, phosphorus, chlorophyll a, and Secchi depth of nine mesohaline inner coastal waters in north east Germany were analyzed from 1990 to 2018. Two pilot mussel farms were used to evaluate their effectiveness as a mitigation measure and to estimate potential environmental risks, including the interactions with pathogenic vibrio bacteria. Further, estimated production and mitigation potential were used to assess economic profitability based on the sale of small sized mussels for animal feed and a compensation for nutrient mitigation. The compensation costs were derived from nutrient removal costs of a waste water treatment plant (WWTP). Results show that currently all nine water bodies do not reach the nutrient thresholds demanded by the WFD. However, coastal waters differ in nutrient pollution, indicating that some can reach the desired threshold values if internal measures are applied. The mitigation potential of mussel cultivation depends on the amount of biomass that is cultivated and harvested. However, since mussel growth is closely coupled to the salinity level, mussel cultivation in low saline environments leads to lower biomass production and inevitably to larger cultivation areas. If $50 \%$ of the case study area Greifswald Bay was covered with mussel farms the resulting nitrogen reduction would increase Secchi depth by $7.8 \mathrm{~cm}$. However, high chlorophyll a values can hamper 
clearance rates $\left(<20 \mathrm{mg} \mathrm{m}^{-3}=0.43 \mathrm{I} \mathrm{h}^{-1}\right.$ dry weight $\left.\mathrm{g}^{-1}\right)$ and therefore the mitigation potential. Also the risk of mussel stock loss due to high summer water temperatures might affect the mitigation potential. The pilot farms had no significant effect on the total organic content of sediments beneath. However, increased values of Vibrio spp. in bio deposits within the pilot farm $\left(1.4310^{6} \pm 1.1010^{6} \mathrm{CFU} 100 \mathrm{ml}^{-1}\right.$ (reference site: $1.0410^{6} \pm 1.4510^{6}$ CFU $100 \mathrm{ml}^{-1}$ ) were measured with sediment traps. Hence, mussel farms might act as a sink for Vibrio spp. in systems with already high vibrio concentrations. However, more research is required to investigate the risks of Vibrio occurrence coupled to mussel farming. The economic model showed thatmussel cultivation in environments below 12 PSU cannot be economic at current market prices for small size mussels and compensations based on nutrient removal cost of WWTPs. 


\section{Blue mussel (Mytilus spp.) cultivation in mesohaline}

\section{2 eutrophied inner coastal waters: mitigation potential, threats}

\section{3 and cost effectiveness}

4 Lukas Ritzenhofen ${ }^{1,2}$, Anna-Lucia Buer ${ }^{1}$, Greta Gyraite ${ }^{1,2}$, Sven Dahlke ${ }^{3}$, Annemarie Klemmstein ${ }^{1}$, Gerald

5 Schernewski ${ }^{1,2}$

$6{ }^{1}$ Leibniz-Institute for Baltic Sea Research Warnemünde, Rostock, Germany

72 Marine Research Institute, Klaipeda University, Klaipeda, Lithuania

$8{ }^{3}$ Biological Station Hiddensee, University of Greifswald, Greifswald, Germany

9

10

11 Corresponding Author:

12 Lukas Ritzenhofen1

13 Seestraße 15, Rostock, 18119, Germany

14 Email address: lukas.ritzenhofen@io-warnemuende.de 


\section{Abstract}

40 The EU-water framework directive (WFD) focuses on nutrient reductions to return coastal

41 waters to the good ecological status. As of today, many coastal waters have reached a steady

42 state of insufficient water quality due to continuous external nutrient inputs and internal loadings.

43 This study focuses first on the current environmental status of mesohaline inner coastal waters to

44 illustrate their needs of internal measures to reach demanded nutrient reductions and secondly, if

45 mussel cultivation can be a suitable strategy to improve water quality. Therefore, nitrogen,

46 phosphorus, chlorophyll a, and Secchi depth of nine mesohaline inner coastal waters in north east

47 Germany were analyzed from 1990 to 2018. Two pilot mussel farms were used to evaluate their

48 effectiveness as a mitigation measure and to estimate potential environmental risks, including the

49 interactions with pathogenic Vibrio bacteria. Further, estimated production and mitigation

50 potential were used to assess economic profitability based on the sale of small sized mussels for

51 animal feed and a compensation for nutrient mitigation. The compensation costs were derived

52 from nutrient removal costs of a waste water treatment plant (WWTP). Results show that

53 currently all nine water bodies do not reach the nutrient thresholds demanded by the WFD. However, coastal waters differ in nutrient pollution, indicating that some can reach the desired depends on the amount of biomass that is cultivated and harvested. However, since mussel growth is closely coupled to the salinity level, mussel cultivation in low saline environments leads to lower biomass production and inevitably to larger cultivation areas. If $50 \%$ of the case

59

60

61

62

63

64

65

66

67

68

69

70

71

72

\section{Introduction}

74 Globally, water quality of coastal ecosystems has deteriorated because of anthropogenic 75 eutrophication. The European Water Framework Directive (WFD, 2000/60/EC) and the 76 European Marine Strategy Framework Directive (MSFD, 2008/56/EC) were implemented to 77 reduce eutrophication, and the Baltic Sea Action Plan (BSAP) expanded and implemented the

78 WFD in the Baltic Sea (Schernewski et al., 2015). The overall aim is to restore the good 
79 ecological status (GES) of aquatic systems by 2027 (WFD, 2000/60/EC). Indicators of the

80 ecological status are submersed macrophytes, zoobenthos, and phytoplankton; nutrient

81 concentrations and water transparency serve as supporting parameters (WFD, 2000/60/EC).

82 In the Baltic Sea, approximately $86 \%$ of coastal waters are below a good trophic status

83 (HELCOM, 2016). In Germany, the water quality of shallow, enclosed, and semi enclosed water

84 bodies are currently rated unsatisfactory or poor (UBA, 2017). However, semi enclosed systems

85 could still reach the turning point and return to a mesotrophic state, if nutrient loads and internal

86 nutrient concentrations are reduced substantially (Berthold et al., 2018; Friedland et al., 2019a).

87 Several internal mitigation measures are already under discussion for the Baltic Sea, including

88 geoengineering approaches like large scale oxygen ventilation (Stigebrandt et al., 2014) and P-

89 precipitation (Rydin et al., 2017), as well as biomass harvesting in terms of commercial and non-

90 commercial fish, bivalves, or water plants (Lindahl, 2012; Petersen et al., 2014; Karstens et al.,

91 2018). Nevertheless, many internal measures are controversially discussed. While some have

92 been associated with high costs and lack feasibility, others are accompanied with undesirable

93 side effects to the aquatic environment, such as damage to benthic habitats or substantial changes

94 in food webs (Naylor, Williams \& Strong, 2001; Stadmark \& Conley, 2011).

95 According to many authors, mussel cultivation seems to be one of the most promising

96 measures(Lindahl, 2012; Petersen et al., 2014; Holbach et al., 2020; Kotta et al., 2020a,b;

97 Wikström et al., 2020). Besides removing nutrients through biomass harvest, mussels can benefit

98 the water transparency as a result of their filter feeding activity (Nielsen et al., 2016, Schröder et

99 al., 2014) and can provide an economically interesting product. Longlines are the common

100 practice of mussel cultivation in the Baltic (Taylor et al., 2019) and, compared to bottom culture,

101 they are most promising for nutrient removal (Buer et al., 2020; Wiles et al., 2006; Filgueira et

102 al., 2018).

103 Mussel mitigation has its limitations though, due mainly to the physiology of mussels. Within the

104 Baltic Sea, only Mytilus spp. and Dreissena spp. are suitable for longline cultivation, as they use

105 byssus threads to attach to the provided collector material (Stybel, Fenske \& Schernewski, 2009;

106 Friedland et al., 2019b).

107 While Mytilus spp. is distributed from full marine conditions to a salinity minimum of 4.5 PSU

108 (Darr, Gogina \& Zettler, 2014; Schiele, Darr \& Zettler, 2014; Schiele et al., 2015; Larsson et al.,

109 2017), Dreissena spp. occurs in Baltic lagoons and bays with up to 5.0 PSU (Ackerman et al.,

110 1994; Fenske, 2005; Stybel, Fenske \& Schernewski, 2009).

111 Even though mussel cultivation has a relatively small negative environmental impact when

112 compared with coastal fin fish aquaculture (Newell, 2004; Dumbauld, Ruesink \& Rumrill, 2009),

113 it is still associated with negative effects on the environment when one looks at intensive

114 production units and the resulting bio deposition (Weise et al., 2009). Increased bio deposition

115 from suspended mussel cultivation can result in organic enrichment of the sediments below

116 mussel farms, increasing benthic mineralization rates and sediment oxygen demands, as well as

117 the release of sediment bound nutrients (Giles, Pilditch \& Bell, 2006; Richard et al., 2007). 
118 These environmental pressures are expected to be stronger in shallow eutrophic coastal waters

119 due to the limited dispersal of bio active material and preloaded sediments.

120 Another threat posed by mussels is the spread of pathogens (Potasman et al., 2002).

121 Most cultivation sides and consumption-mussels are monitored for fecal indicator bacteria

122 (Escherichia coli \& Enterococci), but neglect the risk of other associated bacteria, such as Vibrio

123 (Rincé et al., 2018). The increasing appearance of the pathogenic Vibrio spp. bacteria in

124 eutrophic coastal waters has led to a strong public reaction (Ruppert et al., 2004; Gyraite,

125 Katarzyte \& Schernewski, 2019; Metelmann et al., 2020). Moreover, previous studies show that

126 filter feeders can accumulate bacterial pathogens and act as a reservoir of Vibrio bacteria

127 (Cavallo \& Stabili, 2002; Stabili, Acquaviva \& Cavallo, 2005); thus, mussel cultivation in

128 eutrophic environments may promote Vibrio abundancy and increase the risk for humans and

129 other marine species (Callol et al., 2015; Ina-Salwany et al., 2019).

130

131

This study investigates the ecological status of inner coastal waters and their demands to reduce

132

nutrients to reach the target values required to ensure the GES, and if blue mussel cultivation can

133 be a suitable mitigation tool for this purpose.

134

The objectives of this study are to (a) document the long term development of nutrients,

135 chlorophyll $a$ concentrations, and water transparencies in mesohaline inner coastal waters of the

136 south western Baltic, to identify quantitative needs of nutrient and phytoplankton removal; (b)

137 present the ecological results of a test mussel farm in Greifswald Bay; (c) calculate and assesses costs associated with mussel cultivation as a mitigation measure; and (d) discuss the quantitative potential and cost-effectiveness of blue mussel cultivation as a means to reach GES within the WFD and the potential of farming in other mesohaline inner coastal waters.

141

142

143

\section{Methods \& study site}

144

\section{Study site}

145

The coast of the federal state Mecklenburg-Vorpommern is characterized by several bays, backwaters (Haffe), estuaries and lagoons embedded by islands and peninsulas that form the inner coastal waters (Fig.1). Salinity classifies two types of inner coastal waters for the German Baltic coast: oligohaline (0.5 to 5-6 PSU) and mesohaline inner coastal waters (5-6 to 18-20 PSU) (Schernewski et al., 2004).

Wismar Bay and Salzhaff in the west are both part of the Bay of Mecklenburg with an intense water exchange with the open Baltic Sea (Schlungbaum \& Baulder, 2001).

The Warnow Estuary, surrounded by the city of Rostock, is the transition zone between the river Warnow and the Baltic Sea. Salinity levels in the Warnow Estuary are strongly influenced by stratification caused by river water and Baltic water inflow. The Barther Bodden is part of the Darß-Zingst Bodden chain. Its salinity level is indirectly influenced by water exchange from the open Baltic Sea and the oligohaline Bodstedter and 
158 Kleiner Jasmunder Bodden, and Nordrügensche Bodden all form the coastal lagoons around the 159 Island of Rügen. Salinity levels of coastal lagoons vary according to direct or indirect water 160 exchange with the Baltic Sea (Fig. 1, Tab.1).

161 The GWB is the biggest inshore basin located in north east Germany, limited by the mainland to 162 the south and the Island of Rügen to the West. The average water depth is $5.8 \mathrm{~m}$, with a 163 maximum depth of $13.6 \mathrm{~m}$. Sediment types consist mostly of mud, sand, and clay gravel164 mixture. Based on the lack of hard substrate (Kanstinger et al., 2018), only a limiting and or 165 fluctuating) Mytilus spp. stock can be expected. It is most likely that mussel larvae enter GWB 166 from mussel beds outside, which can be found on reef structures around Rügen Island (Darr, 167 Gogina \& Zettler, 2014). Salinity levels range from 6-8 PSU. Water temperatures are highly 168 influenced by seasonal atmospheric temperature regimes.

170

The GWB plays an important role, both ecologically and economically. While tourism and coastal fishing are essential for local employment (Obernaus \& Köhn 2002; www.statistikmv.de), the GWB serves also as an important spawning ground of the herring stock in the western Baltic Sea (Kanstinger et al., 2018). High nutrient inputs in the past have led to heavy eutrophication (Munkes, 2005). As a result, submersed macrophyte cover declined from $90 \%$ to $15 \%$ and the GWB turned into a phytoplankton-dominated ecosystem (Munkes, 2005).

Altogether, it seems that present mitigation measures in the catchment area are not sufficient to return to a GES and supporting internal measures are needed.

\section{Hydro-chemical and biological data analysis}

The hydro-chemical and biological data were provided by the State Agency for Environment, Nature Conservation and Geology Mecklenburg-Vorpommern (LUNG). Monitoring stations provide monthly data for total nitrogen (TN) and phosphorus (TP), dissolved inorganic nitrogen and phosphorus, Chl. $a$ concentration, and Secchi-depth for the period from 1990-2018. Dissolved inorganic nitrogen (DIN) is the sum of nitrate, nitrite, and ammonium. Samples for dissolved nutrients were stored dark until filtration through cellulose-acetate filters (pore size $0.45 \mu \mathrm{m}$ ) followed by freezing. Dissolved inorganic phosphorus (DIP) was determined as soluble reactive phosphorus by using the molybdenum blue method (Strickland and Parsons, 1972). The percentage share of non-bioavailable DIP was not determined. TP and TN were digested in a microwave with peroxodisulfate (DIN11905-1 1998). Total and dissolved nutrients were measured in a continuous flow analyser (Skalar Inc., later Alliance Instruments (Malcolm-Lawes and Wong 1990; DIN13395 1996; DIN11905- 1 1998; DIN11732 2005). Chl. $a$ was determined fluorometrically $(665 \mathrm{~nm})$ after filtration $(\mathrm{GF} / \mathrm{F}, 0.7 \mu \mathrm{m})$, extraction with ethanol, and acidification (ISO 10260:19922).

To evaluate whether internal mitigation measures are suitable, time series analysis of total nutrients (TN \& TP), Chl. $a$ concentration, and Secchi depth were conducted for the period between 1990 and 2018. The data was split into three periods and average annual concentrations from 1990-1999, 2000-2009, and 2010-2018 were compared. The time series were analyzed using the Mann-Kendall test to identify whether the measured values of the time series are 
199

200

201

202

203

204

205

206

207

208

209

210

211

212

213

214

215

216

217

218

219

220

221

222

223

224

225

226

227

228

229

230

231

232

233

234

235

236

237

238

randomly distributed or if trends occur in the data. The level of significance was set to 0.05 . Afterwards, values were compared with new WFD target concentrations (Schernewski et al., 2015).

A general approach to managing eutrophication is the control of nutrient loads (N, P) essential for primary production. It has to be known weather phytoplankton biomass responds to changes in nitrogen or phosphorous in the water column. To investigate this, monthly DIN/DIP ratios and Chl. $a$ concentration for all water bodies were compared. Simple linear regression was used to describe the monthly relationship between TN or TP to Chl. $a$ concentration. To investigate how nutrient reduction potentially improves water transparency, simple linear regression models were used as well. Data was ln-transformed when necessary.

\section{Pilot blue mussel farms setup}

Pilot farm 1 is located in the Hagensche Wiek, a bay in the north eastern part of GWB (Fig. 1). The cultivation unit consisted of 5 parallel longlines (Fig. 2). Each longline moored in a depth between 5.0 and $6.0 \mathrm{~m}$ using dead weight anchors of $250 \mathrm{~kg}$. Every longline was attached with $50 \mathrm{~m}$ collector material, consisting of $1 \mathrm{~mm}$ thick and $50 \mathrm{~mm}$ wide polypropylene bands reaching up to $3.5 \mathrm{~m}$ water depth. Pilot farm 1 was deployed in April 2017 and was operated until October 2019. During the operating period, the collector material was used for spat collection and mussel grow out.

A smaller test farm (pilot farm 2) was located in the Wieker Bay (WB) (Fig. 1). The setup consists only of two longlines, each $10 \mathrm{~m}$ long (Fig. 2). The collector band material matches the one of pilot farm 1 and the loops extended from $1 \mathrm{~m}$ to $1,5 \mathrm{~m}$. Pilot farm 2 was deployed in June 2017.

\section{Field and laboratory experiments}

Mesocosm experiments were carried out at GWB and WB to estimate the individual clearance rate at high Chl. a concentrations of Mytilus spp. The reduction of Chl. $a$ was measured using an in vivo fluorometer (Algae Torch, bbe-Moldaenke, Germany).

Additional laboratory experiments tested different Chl. $a$ concentrations and their effect on the clearance rate (CR) of Mytilus spp. During the laboratory experiments, different concentrations of Rhodomonas spp. were added to a well-mixed and aerated aquarium with defined volume of artificial seawater and a group of mussels $(\mathrm{n}=20)$. The reduction of Chl. $a$ concentration was measured using a handheld fluorometer (AquaFluor, Turner Designs, USA). The clearance rate was determined by the exponential decrease in Chl. $a$ concentration as a function of time using the equation $\mathrm{CI}=\mathrm{a}^{*}(\mathrm{~V} / \mathrm{n})$, where $\mathrm{V}=$ volume of water, $\mathrm{n}=$ number of filtering mussels, and $\mathrm{a}=$ slope of the regression line in a semi-ln plot of the reduction of Chl. $a$. Measurements were repeated three times. Control runs without mussels were conducted to evaluate possible sedimentation. Mesocosm and laboratory experiments were conducted at water temperatures of $20^{\circ} \mathrm{C}$. 
239 Nutrient harvest yields were estimated by the nitrogen and phosphorus content of cultivated blue 240 mussels. Mussel tissue and shells of all individuals were pooled, freeze- dried, and ground prior 241 to analyzing carbon and nitrogen with an auto-analyzer (Elementaranalysator EA 3000).

242 Phosphorous was determined in mussel ash using an alkaline persulfate oxidation after Hansen 243 and Koroleff (1999).

244

245 The bio deposition of faeces and pseudo-faeces was measured with sediment traps. The traps 246 were deployed within the GWB farm and at a reference point $100 \mathrm{~m} \mathrm{SW}\left(\mathrm{N} 54^{\circ} 18,839\right.$;

247 E13 $\left.{ }^{\circ} 40,728\right)$ in May 2018. Additionally, sediment traps were deployed at a commercial mussel 248 farm $($ Farm size $=1$ ha $)$ in the Kiel Fjord. Trap contents, including all suspended particles, were filtered onto Whatman GF/F filters, dried, and weighed. Total organic content (TOC) was measured as loss on ignition. Furthermore, sediment samples were taken within GWB farm and the reference point. Subsequently, TOC was measured as loss on ignition of dry matter.

252

253

254

255

256

257

258

259

260

261

262

263

264

265

266

267

268

269

270

271

272

273

274

275

276

277

278 To measure the Vibrio spp. abundance within the pilot mussel farm in GWB and the reference location, samples were taken of surface water, sediments, sediment traps and mussels.

The total number of Vibrio spp. from water samples was determined by filtering water volumes of 10 and $50 \mathrm{~mL}$ through $0.45 \mu \mathrm{m}$-pore-size mixed cellulose ester filters (MontaMil ${ }^{\circledR}$ Membrane Filters, Frisenette ApS, Knebel, DK). All filters were placed onto thiosulphate-citrate-bilesaltssucrose agar plates (TCBS agar) (SIGMA-ALDRICH, Missouri, US1A) and incubated for $24 \mathrm{~h}$ at $37^{\circ} \mathrm{C}$. Sediment and sediment trap samples were serially diluted and plated on TCBS agar. Fresh mussel samples collected at the mussel farm were transported in cooling boxes and processed within 8 hours of collection. Sample preparation and homogenization was done according to the CEFAS Standard Operating Procedure - Detection of Vibrio parahaemolyticus in Bivalve Molluscan Shellfish (www.crlcefas.org). Serially diluted sample homogenate was plated on TCBS agar. After $24 \mathrm{~h}$ of incubation, colonies were counted and the number of total Vibrio determined as colony forming unit (CFU) $100 \mathrm{~mL}^{-1}$ for water, CFU $100 \mathrm{~g}^{-1}$ for sediment samples and $\mathrm{CFU} \mathrm{\textrm {g } ^ { - 1 }}$ mussel tissue.

\section{Economic calculations}

Data for the economic calculations are based on the investment and maintenance costs of pilot farm 1 in GWB. Since pilot farm 1 was a scientific mussel farm and therefore without annual running cost (that would otherwise be faced by a commercial business), supplementary data were derived from a commercial mussel farm in Kiel Fjord (Krost et al., 2011).

Krost et al. (2011) predicted annual yields of $25 \mathrm{t}$ and $100 \mathrm{t}$ of mussels for human consumption after 18 months. Annual running costs include anchoring and foundation, longlines, buoys, floaters, socks, collectors, and staff. The economic lifetime varied between 1 and 5 years. Investment costs covering a boat and machinery (both with an assumed lifetime of 5 years), as well as a land station, were summarized under annual investment costs. Since staff is the dominating cost factor, the salaries from the year 2010 (Krost et al. 2011) were recalculated for the year 2020 assuming an increase of $30 \%$ (the statistical average salary increase in Germany). 
279 With increasing farm size, we assumed that staff and investment costs decrease steadily per 280 produced ton of mussels; this decrease is relatively high in smaller farms and negligible in very 281 large units.

282 The salinity in GWB only allows for the production of mussels for mussel meal or feed, 283 harvested after about 12 months of cultivation time. As a consequence, we assumed lower 284 production costs with a reduced staff effort of $50 \%$ and $2 \%$ lower investment costs. These 285 numbers are based on our own experiences with our two small pilot farms and verified by 286 discussions with experts from the commercial mussel farm sector and literature.

287 The annual production of feed mussels in GWB is assumed to be $0.278 \mathrm{~kg} \mathrm{~m}^{-3}$ cultivation 288 volume. This data is based on a model simulation study in Buer et al. (2020) and verified by our

289

290

291

292

293

294

295

296

297

298

299

300

301

302

303

304

305

306

307

308

309

310

311

312

313

314

315

316

317 experimental farms. Assuming a cultivation volume from the surface to a depth of $3 \mathrm{~m}$, and taking into account the relatively low productivity, a farm producing $100 \mathrm{t}$ mussels per year would cover a surface area of about 120 ha. The nitrogen (phosphorus) content in mussels is assumed to be 0.008 (0.0006) $\mathrm{kg} \mathrm{kg}^{-1}$ fresh mussels, based on the cultivated mussels in GWB. In addition to the production of feed mussels, we assumed a compensation for nutrient extraction based on the removal costs of a wastewater treatment plant (WWTP). The revenue for nitrogen and phosphorus removal is set at 30,000 $€ \mathrm{t}^{-1}$ and $80,000 € \mathrm{t}^{-1}$ (COWI 2007; Gren, Jonzon \& Lindqvist, 2008; Hautakangas et al., 2014).

\section{Results}

\section{Bio-chemical status of coastal waters}

Although all nine study sites were similar, their ecological status and its temporal development differed strongly (Fig. 3). The majority had average annual TN concentrations between 20-50 $\mu \mathrm{mol} \mathrm{1^{-1 }}$, TP concentrations between 1-2 $\mu \mathrm{mol} \mathrm{l}^{-1}$, and Chl. $a$ concentrations between 5-20 $\mathrm{mg} \mathrm{m}^{-}$

3 . Consequently, all coastal waters were regarded as eutrophic, their ecological status was classified as unsatisfactory (LUNG 2013), and a need for measures to improve water quality was apparent. During the 1990s, the technical improvement of WWTPs caused a strong reduction of nutrient loads to coastal waters in the Federal State of Mecklenburg-Vorpommern, Germany. The largest five WWTPs reduced TP loads by more than $95 \%$ and TN loads by over $80 \%$ (LUNG 2013). As a result, the riverine loads declined by about 70\% (TP). A significant decline in TN loads did not take place during the last 30 years. The riverine loads closely correlate with the river discharge. This is true for the TP loads after 1996, as well (LUNG 2013). In seven of the coastal waters, the load reductions during the 1990s caused a decline in TN and TP annual concentrations (Fig.3), but only two showed reductions in Chl. $a$ concentrations and only three increased water transparency. After 2000, the nutrient concentrations in the coastal waters did not indicate significant changes. Since the riverine loads were largely stable during the past decades, it can't be expected that a reduction in nutrients in coastal waters will take place in the future without new, additional measures. Further, it seems unrealistic that additional external load reductions will be implemented 
318 After 2000, the Chl. $a$ concentrations did not show a significant decline. In most coastal waters, 319 positive effects on water transparency were not visible either. Exceptions were the Barther 320 Bodden, the Jasmunder Bodden, and the Warnow Estuary. It is very likely that the status of the 321 two Bodden waters improved as a result of reduced diffuse agricultural nutrient loads. The

322 Warnow Estuary, as a shipping channel, was subject to several dredging activities. This

323 increased the water exchange with the Baltic Sea and reduced the nutrient and Chl. $a$ levels. In

324 general, the nutrient and Chl. a levels seem directly related to the water exchange time and the

325 shallowness of systems. A low water exchange time and a large euphotic zone (low average

326

327

328

329

330

331

332

333

334

335

336

337

338

339

340

341

342

343

344

345

346

347

348

349

350

351

352

353

354

355

356

357 water depth) are likely reasons for the very high nutrient and Chl. $a$ concentrations in the Kleiner Jasmunder and the Barther Bodden, as well. On the other hand, the relatively strong reductions in nutrients and Chl. $a$ concentrations in both water bodies over the last decades indicate a distinct reaction to changes in loads. The water exchange time and the average depths are parameters that determine the effectiveness of internal measures in coastal waters.

The sensitivity of aquatic systems is one factor that determines how promising a potential internal measure will be. Another factor is the present state of pollution and its deviation from the good ecological status. Figure 3 indicates the desired threshold values, according to the WFD for each coastal water. Wismar Bay and Salzhaff are already close to a good status and efforts to reduce diffuse loads might already be enough to meet the threshold. While for the Warnow Estuary, the West/Nord Rügener Bodden, and Strelasund and Greifswalder Bodden it seems possible to meet the good status, it would require additional internal measures. Thanks to its size and importance for fishing and recreating, the Greifswalder Bodden is the best case study for assessing the suitability of mussel farming to improve ecological status.

\section{Seasonal nutrient and chlorophyll relationships}

During the winter, primary production in Baltic coastal waters is limited by temperature and light. The increase of Chl. $a$ concentrations and decrease of dissolved inorganic nutrient concentrations that takes place during the spring and summer indicates that nutrients become a potentially limiting resource for phytoplankton biomass in most water bodies (Tab. 2.). In all coastal waters, DIN concentrations strongly decline between late winter and summer. For DIP, the decline takes place earlier and by March concentrations are low. The molar N/P ratio of 16 (according to Redfield) provides a rough estimate for which nutrient is limiting primary production.

During March and April, high nitrogen discharges initiate blooms in coastal waters; the average DIN:DIP ratio ranged from 26 to 720, indicating a P limitation (Tab.2). In May, most water bodies show a shortage of DIP. In June, phytoplankton growth reliance begins to change towards a shortage of N. During July, the majority of the waterbodies show an average DIN:DIP ratio between 2-10, indicating an N shortage. In the Wismar Bay, Nord/West Rügener Bodden, and Strelasund and Greifswalder Bodden, this situation remained the same through August and September (Tab. 2.), whereas the Salzhaff and Warnow Estuary returned to an N/P ratio of close to 16:1 during this time. Only the shallow Kleiner Jasmunder Bodden and the Barther Bodden were exceptions. Here, the Chl. $a$ concentrations decreased from May until July and absolute 
358

359

360

361

362

363

364

365

366

367

368

369

370

371

372

373

374

375

376

377

378

379

380

381

382

383

384

385

386

387

388

389

390

391

392

393

394

395

396

397

dissolved inorganic nutrient concentrations fluctuated but were relatively high (Tab. 2.). Results indicate that phytoplankton growth is not controlled by the availability of nutrients but rather by other parameters, such as turbidity and light.

The GWB is representative of coastal waters due to its short availability of $P$ in the spring and a shortage of $\mathrm{N}$ between July and September.

This is shown for GWB in Fig. 4. Between March and September, the Chl. a concentration shows a close positive correlation to TN and TP concentrations.

This has several implications: (1) nutrients have a controlling function for phytoplankton biomass and as a consequence, measures that reduce nutrient concentrations in the water (such as mussel farming) will cause a reduction in phytoplankton concentrations and have a positive effect on water quality; (2) especially between July and September, the availability of $\mathrm{N}$ seems to control the productivity; summer is exactly the time when mussels show the fastest growth and are most efficient at removing nutrients from the water column via phytoplankton filtration and uptake.

\section{Improvement of water quality during summer}

Chl. $a$ concentration and Secchi depth are related during the summer (the main grow out season for mussels) and therefore directly connected to the mitigation process of mussel farming. The linear regression shows a strong negative relationship between total nitrogen and Chl. $a$ concentrations during July up until September (Fig. 5, A). Secchi depth can be better explained by Chl. $a$ than total suspended solid concentration (TSS) (Fig. 5, B \& D). Autocorrelation between TSS concentration and phytoplankton biomass results in a close regression coefficient because biomass is a natural part of TSS. The stronger coefficient of determination, however, affirms that Secchi depth can be better described by Chl. $a$ concentration. Based on the prior linear regression model between TN and Chl. $a$ concentration, a regression model describing the relationship between TN and Secchi depth was established to describe water quality improvements when nitrogen is mitigated (Fig. 5, C).

According to linear regression model A (Fig. 5), Chl. $a$ concentration can be reduced to approx. $1.4 \mathrm{mg} \mathrm{m}^{-3}$ if total nitrogen concentration is reduced to the threshold value of $16.9 \mu \mathrm{mol} \mathrm{1-1}$. Based on the relationship between Secchi depth and TN concentration (C), Secchi depth would increase by approx. $70 \mathrm{~cm}$. Given that GWB has a monthly water exchange rate, the reduction effort has to be accomplished on a monthly basis.

Monthly nitrogen reductions would result in annual values of $41.6 \mu \mathrm{mol} \mathrm{l}^{-1} \mathrm{TN}$ and $10.6 \mathrm{mg} \mathrm{m}^{-3}$ Chl. $a$ concentration, accounting for a reduction of $15.5 \% \mathrm{TN}$ and $29.8 \% \mathrm{Chl} . a$ of the mean annual concentration.

\section{Water quality improvement by mussel farming}

In situ investigations of clearance rates (CR) of blue mussels from the two pilot farms showed overall low clearance rates compared to laboratory CR investigations. Mytilus spp. from the pilot farm 2 showed slightly higher CRs at a lower ambient Chl. $a$ concentration $\left(15 \mathrm{mg} \mathrm{m}^{-3}\right)$ than 
398

399

400

401

402

403

404

405

406

407

408

409

410

411

412

413

414

415

416

417

418

419

420

421

422

423

424

425

426

427

428

429

430

431

432

433

434

435

436

437

Mytilus spp. from pilot farm 1 with a higher ambient Chl. a concentration $\left(22 \mathrm{mg} \mathrm{m}^{-3}\right)$.

Laboratory tests revealed a significant decrease in CR with increasing Chl. $a$ concentration exceeding $20 \mathrm{mg} \mathrm{m}^{-3}$ (Fig. 6, A.). Based on these results, Chl. $a$ is an important driver effecting blue mussel CRs.

Nutrient contents of the mussels (wet weight total) did not differ significantly between both pilot farms, indicating that neither salinity nor Chl. $a$ concentration influence the nutrient content (Fig. 6, B.).

Rapid growth rates in the first few months lead to high nutrient extraction capacities per month. The first settling of mussel larvae at pilot farm 1 was recorded in July. During August, juvenile mussels had an average total wet weight of $17.78 \pm 5.44 \mathrm{mg}$ per mussel, while in September the average wet weight already reached $147.01 \pm 28.40 \mathrm{mg}$ per mussel. During August and September, TN concentrations in GWB ranged between 41.5 to $40.0 \mu \mathrm{mol} \mathrm{l}^{-1}$ (equaling approx. 1700 t $\mathrm{N}$ within GWB).

Subsequently, if $50 \%$ of the GWB was covered with mussel farms, it would take up $257 \mathrm{t} \mathrm{N}$ and reduce TN concentration to $34.6 \mu \mathrm{mol} \mathrm{l}^{-1}$ by September (Tab. 3). According to the linear regression model (Tab. 3, C), reduced nitrogen would increase the Secchi depth by $7.83 \mathrm{~cm}$. Our results also show that if mussel farming is used locally in areas with a low water exchange rate, the effect of mussel farming can be extended. Based on the other water bodies that have no direct water exchange with the Baltic Sea (Tab. 1), we assumed that the Hagnesche Wiek (location of pilot farm 1 (Fig. 1)) has a lower water exchange rate of approx. 6-7 $\mathrm{a}^{-1}$. Here, the results show that the TN concentration could be reduced to $32.1 \mu \mathrm{mol}^{-1}$ and Secchi depth would increase by $10.6 \mathrm{~cm}$ (Tab. 3).

In addition to water transparency improvements seen by reducing nitrogen concentration, the mussels improve water transparency by removing phytoplankton. Taylor et al. (2020, in submission) calculated an average depletion of 5\% from autumn 2017 to summer 2018 for pilot farm 1. According to the linear regression model (Fig. 5, B), the reduction of Chl. $a$ concentration from a mussel farm occupying 50\% would increase Secchi depth by an additional $13.3 \mathrm{~cm}$, resulting in a total improvement of $\sim 20 \mathrm{~cm}$.

Our results clearly show that the cultivation of small sized mussels in low salinity environments must cover a substantial amount of surface area to have a severe impact on water quality. This, however, can create a tradeoff between potential improvements in water quality and negative effects emerging from the mussel farm.

\section{Potential negative ecological effects of mussel cultivation in GWB}

The primary negative effects of suspended mussel cultivation are nutrient enrichment of benthic habitats and the spread of pathogens.

While sediment TOC was not significantly influenced by the mussel farm in GWB (Fig. 7), during 2018 an increasing trend of TOC was indicated beneath the pilot farm. This might be explained by the fact that during 2018, the mussel farm was fully stocked (resulting in a higher 
438 bio deposition rate). Additionally, by the end of the summer, $80 \%$ of the mussel stock was lost 439 after mussels detached and sunk, inadvertently increasing overall organic content at the seafloor. 440 Bio deposition was higher over the summer at pilot farm 1 than at the reference site. This was 441 also confirmed by results from the Kiel Farm (Fig. 7). Results obtained from the commercial 442 farm, however, showed lower bio deposition compared to GWB, even though the commercial 443 farm was bigger in size and stock density. It has to be mentioned that measurements were not 444 obtained at the same time. While GWB measurements were taken in June, measurements at the 445 commercial farm were taken in October. Therefore, it can be assumed that in GWB the 446 sedimentation of phytoplankton adds to the content of bio deposition produced by mussels, 447 leading to significant increased values.

448 The Vibrio spp. concentration in cultivated blue mussels was $1.0710^{4} \pm 1.7510^{3} \mathrm{CFU} \mathrm{g}^{-1}$ (Fig. 449 8). Higher concentrations of Vibrio spp. were found in the surface water and sediment at the 450 reference points. However, sediment trap samples showed increased Vibrio spp. concentrations 451 in the pilot farm 1 compared (Fig. 8).

452 The results show that Vibrio bacteria are concentrated in feces and pseudo feces in the water 453 column within the mussel farm, and concentrations in sediments are lower. This may be an 454 indication that bio deposits are further distributed and not concentrated directly beneath the 455 mussel farm.

456

\section{Economic assessment of mussel cultivation in GWB}

Based on the expected mussel yields in GWB, our results show that mussel mitigation with the revenues from feed mussel sales and nutrient removal will not be profitable in GWB (Fig. 9). Even though annual costs decreased with increasing production volume, the net balance remained negative. Revenues from nutrient reduction can only narrow the gap towards cost neutrality. In GWB, cost neutrality is not reached because the small sized mussels can only be sold as feed mussels for a minor sales price of $0.06 € \mathrm{~kg}^{-1}$. In comparison, fresh blue mussels for human consumption could be sold for $11.0 € \mathrm{~kg}^{-1}$. According to Buer et al. (2020a), mussel cultivation for human consumption is only possible at a salinity threshold of 12 PSU, indicating that mussel mitigation in Wismar Bay and Salzhaff and Warnow Estuary could be profitable if mussels can be sold for human consumption instead of animal feed.

In GWB, a farm size of approx. 200 ha would reduce the cost gap to under 1,000 $€$. This gap could be closed if water transparency improvements were compensated, as well.

Depending on the production volume, nutrient removal costs would range between 40 to $814 €$ $\mathrm{kg} \mathrm{N}^{-1}$ and 899 to $18,000 € \mathrm{~kg} \mathrm{P}^{-1}$. Even if mussel production volume increases, nitrogen extraction by mussels is more expensive than other land-based measures (Fig.9 B). Mussel mitigation becomes logical when nutrient pollution is caused by internal processes or when landbased measures have reached their feasibility limit.

\section{Discussion}


477 During recent years, suspended mussel farming has progressed as a novel approach to mitigate 478 eutrophication and support underwater vegetation (Lindahl \& Kollberg, 2008; Schernewski, 479 Stybel \& Neumann, 2012; Friedland et al., 2019a; Petersen, Loo \& Taylor, 2019; Timmermann 480 et al., 2019).

481 So far, reductions in nutrient inputs through the EU's Urban Waste Water Treatment Directive, 482 the modernization of WWTP, and changing agriculture practice (Munkes, 2005; Selig et al., 483 2006; Boesch, 2019) have not been enough to improve the ecological status in regards to Chl. $a$ 484 concentration and water transparency. Instead, after 2000 there was a stagnation in nutrient 485 reductions across most inner coastal waters of north east Germany and WFD targets were not 486 met.

487 Nevertheless, most water bodies could potentially reach the target values demanded by the WFD 488 if nutrient loads were further reduced and internal restoration measures implemented. This is 489 facilitated by the fact that climate change in north east Germany will most likely reduce diffuse 490 nutrient run off and nitrogen pollution further. Longer droughts and less rain in the summer 491 might limit crop production and the use of nitrogen fertilizer (Spekat, Enke \& Kreienkamp, 492 2007; Jacob et al., 2008; Borken \& Matzner, 2009). This could further shorten the gap to the 493 desired annual target values and make internal mitigation more effective (Williges et al., 2017). 494 Overall, the results show that in the summer, the availability of nitrogen controls phytoplankton 495 productivity. Therefore, by further shortening the nitrogen supply during the summer, 496 phytoplankton growth can be hampered and water transparency can be improved (Nielsen et al., 497 2002).

498

Mussel farming as an internal mitigation measure is capable of reducing nutrients up to 0.6-3.01 t $\mathrm{N}$ ha-1 and 0.03-0.17 t P in Danish waters, depending on the farming strategy and harvesting time (Petersen et al., 2014; Taylor et al., 2019). Timmermann et al. (2019) showed that blue mussel farming in the eutrophied Danish Skive fjord decreased summer Chl. $a$ concentration by

504 $30 \%$ and light attenuation up to 14\%. Improvements were also obtained in Sweden and Germany

505 However, our results have shown that mussel cultivation in shallow coastal waters can be subject 506 to risks and success depends very much on the ecosystem and prevailing conditions.

507 The osmotic stress based on the salinity gradient in the Baltic has the most dominant effect on 508 blue mussel growth and health (Buer et al., 2020; Maar et al., 2015; Riisgård et al., 2012;

509 Westerbom et al., 2002) and therefore also on the mitigation effect.

510 Another factor which can affect the mitigation potential is the loss of mussel stock. Loss of 511 mussels can be caused by different events e.g. by predators such as eider ducks, damage or loss

512 of farm structures as well as changing environmental parameters such as high water temperatures 513 during summer (Varennes et al., 2013; Jones et al., 2010; Ross \& Furnes 2000;). Especially, in 514 shallow coastal waters with limited water exchange rates high water temperatures can appear 515 during summer. Fly and Hilbish (2013) stated that the energetic balance of M. trossulus is 516 affected by water temperatures above $17^{\circ} \mathrm{C}$. Other studies have shown that byssus threads are up 
517 to $60 \%$ weaker at water temperatures of $25^{\circ} \mathrm{C}$ than at $10{ }^{\circ} \mathrm{C}$ (Newcomb et al., 2019).

518 Westerbrom et al. (2019) concluded that temperature stress coupled with continuous salinity

519 stress may also cause increased mortality. Therefore, there is an increased risk at low salinities

520 that mussels detach, die off and increase the organic pressure on the sediment below, while at the

521 same time decrease mussel harvest.

522

523 In addition, enclosed shallow coastal waters often suffer from internal loading and resuspension, 524 fuelling high phytoplankton biomass and particular matter (Schiewer, 1997; Selig et al., 2006)

525 which can also impact the effectiveness of mussel mitigation (Schulte, 1975; Riisgard, 1991).

526 Mesocosm and laboratory experiments showed lower CRs at high Chl. a concentrations (Fig.

527 6A), supporting previous studies (Clausen \& Riisgård, 1996, Riisgård et al., 2003, Soon et al.,

528 2016). Clearance rates in mesocosm experiments were significantly lower than under laboratory

529 conditions, most likely because mussels under laboratory conditions were fed a Rhodomonas sp.

530 diet optimal for Mytilus spp. (Fernández-Reiriz et al. 2015). Three of the assessed water bodies

531 (Barther Bodden, Kleiner Jasmunder Bodden, Nord Rügener Bodden) exceed Chl. a

532 concentration of $20.0 \mathrm{mg} \mathrm{m}^{-3}$ throughout the entire summer, while others, e.g. Greifswalder

533 Bodden andf Strealsund, exceed these only at the end of summer (August, September).

534 Comparing results of the present study with available models, e.g. the Farm Aquaculture

535 Management System (FARM), it becomes apparent that the effectiveness of mussel mitigation is

536 hampered by Chl. a concentrations above $20 \mathrm{mg} \mathrm{m}^{-3}$. For example, the FARM model calculates

537 an Assessment of Estuarine Trophic Status (ASSETS) score of "moderate" in regard of the late

538 summer Chl. a concentrations of $\operatorname{GWB}\left(>20.0 \mathrm{mg} \mathrm{m}^{-3}\right)$. If the Chl. a concentration is set to 10.0

$539 \mathrm{mg} \mathrm{m}^{-3}$ the calculate ASSETS score reaches "good".

540

541 Even though there was no significant difference in nutrient content (total DW was detected

542 between blue mussel samples from both pilot farms), mussel samples from pilot farm 1 had a

543 lower nutrient content in total WW. Mussels of this farm had a higher water content due to lower

544 salinity, supporting the results of Maar et al. (2015). With increasing salinity, the nutrient storage

545

546

547 One of the greatest concerns regarding intense mussel farming is enhanced local bio deposition

548 beneath mussel farms (Nizzoli et al., 2005; Giles, Pilditch \& Bell, 2006; Callier et al., 2009;

549 Giles et al., 2009). Surveys of benthic conditions beneath mussel cultivation sites in shallow

550 coastal embayment's ( $2 \mathrm{~m}-10 \mathrm{~m}$ water depth) in Canada revealed that after a production increase

551 of $43 \%$ (approx. $20 \times 10^{3} \mathrm{t} \mathrm{y}^{-1}$ in 2001) organic matter (TOC) also increased significantly.

552 Furthermore, after a cultivation period of two years, approx. 50\% of the sediment beneath the

553 cultivation site was permanently anoxic and dominated by white sulfur bacteria mats (Cranford

554 et al., 2009; Hargrave, 2015). Due to the small size and fluctuating stock density of the pilot

555 farms in this study, there was no significant enrichment of sediment TOC. 
556 Increased bio deposition in GWB during the summer and at the larger farm in the Kiel Fjord, 557 however, support previous studies and point towards a risk of increased TOC if farm units 558 exceed a size specific for the ecosystem.

559

560

561

562

563

564

565

566

567

568

569

570

571

572

573

574

575

576

577

578

579

580

581

582

583

584

585

586

587

588

589

590

591

592

593

594

595

596

Filter feeders like blue mussel also accumulate pathogens from the surrounding water (Canesi et al., 2002). Especially in the summer months, when water temperatures are high, Vibrio species are highly abundant in coastal waters (Eiler et al., 2007; Baker-Austin et al., 2013). Collin et al. (2012) stated that blue mussels are able to accumulate around $98 \%$ of marine Vibrio species within a 24-hour period and, due to their robust immune systems, can eliminate these pathogens (Balbi et al., 2013; Tanguy et al., 2013). However, our results show that Vibrio spp. are concentrated by mussels and released into the water column through feces and pseudo feces, indicating that the mussel immune system was not able to effectively erase Vibrio bacteria. In this study, total Vibrio spp. abundance obtained from the mussel's tissue was approximately 2 times higher than $10^{2}-10^{3}$ of CFU per gram described in Huss (1997). High concentrations paired with a reduced immune response caused by environmental stressors (Rahman et al., 2019) might explain the release of viable bacteria. Pietrak et al. (2012) also argued that it is possible that Vibrio bacteria are released in the form of pseudo feces production without passing through the digestive system. In both cases, mussels and mussel farms could act as a sink of potentially pathogenic Vibrio bacteria in the water column (Callol et al., 2015; Ina-Salwany et al., 2019). Even though high concentrations were observed in the bio deposits in the water column, the sediment concentrations did not increase compared to the reference site.

In both cases, when considering increased bio deposition and Vibrio concentration, the pilot farm was too small to have an impact on the sediment beneath. Since it can be expected that bigger farms in inner coastal waters will have a significant impact on the environment, more research regarding ecological and pathological tradeoffs is needed.

The profitability of mussel cultivation can be an important factor in the selection and acceptance of a mitigation measure. Buer et al. (2020a) described the effects of the salinity gradient along the German Baltic coast on blue mussel farming and its economic implications. The authors state that mussel farming here can be profitable only if blue mussels are sold for human consumption. The threshold that this is still feasible is above $12 \mathrm{PSU}$, beyond which point mussel growth is too slow to be profitable (Buer et al., 2020a). Beneath 12 PSU, alternative sale strategies, such as animal feed (Schernewski, Stybel \& Neumann, 2012) or compensation for nutrient removal are proposed.

The results of this study show that even if mussel cultivation generates revenues from feed mussel and nutrient extraction (based on the removal costs of a WWTP), the sales cost balance remains negative and annual investment and running costs cannot be recovered. If blue mussels cannot be sold for human consumption, nutrient mitigation will always be a no-income measure, making it less attractive. Therefore, further funding schemes are necessary. Another option could be a nutrient trading system where the polluter pays for the emission. This is easy to accomplish for point source nutrient inputs, but becomes more challenging if diffuse sources are included

Peer) reviewing PDF | (2020:10:53759:1:2:NEW 10 Mar 2021) 
597 (Ferreira \& Bricker, 2016). Additionally, mussel farming could generate additional income 598 through the improvement of water transparency and its implications on ecosystem services. Tuya 599 et al. (2014) described the monetary values of seagrass meadows that act as nursery grounds for 600 commercially interesting fish species. The results of this study revealed an average monetary 601 value of seagrass meadows of $95.75 € \mathrm{ha}^{-1} \mathrm{y}^{-1}$. The same approach could be applied for German 602 coastal waters and be used to compensate mussel cultivation for increasing water transparency.

603

604

605 Conclusion

606 This study showed that mussel cultivation in inner coastal waters can act as a nutrient and 607 phytoplankton sink during the summer and, potentially increase water transparency and light 608 availability for submerged macrophytes. However, depending on physical and biological 609 restrictions, mussel cultivation will have different improvement efficiencies mainly due to the 610 predominant salinity level. Estimations for the case study area GWB, which is with 6-7 PSU a 611 marginal cultivation site, have shown that if 50\% of GWB are used for mussel cultivation, $257 \mathrm{t}$ $612 \mathrm{TN}$ can be bound in mussel biomass. This reduction could increase Secchi depth by $7.8 \mathrm{~cm}$. 613 However, due to the limited mussel growth, this mitigation measure cannot be economic for this 614 site. Further, the mitigation potential can also be affected by unpredicted mussel loss caused by 615 high temperatures. Even though this study showed no negative environmental impacts by mussel 616 farming, it can be assumed that shallow eutrophic coastal waters are especially vulnerable if 617 production volumes were increased. For coastal waters with low salinity levels, a combination of 618 different internal mitigation measures would be recommended.

619 A higher concentration of Vibrio spp. was detected in bio deposits but not in the sediment below 620 the farm in GWB. Nonetheless, further research is needed to investigate if large mussel farms 621 can act as a sink for human pathogens like Vibrio spp. This is especially important for systems 622 that already suffer from high Vibrio spp. concentrations potentially causing a conflict for bathing 623 tourism. Mussel cultivation reaches highest mitigation potential at salinities above 12 PSU and 624 increase at Chl. a concentrations below $20 \mathrm{mg} \mathrm{m}^{-3}$. However, including economic estimations, 625 mussel farming will not be cost neutral mitigation measure based on the current market prices for

\section{Acknowledgement}

633 We would like to thank M. V. Weber (LUNG-MV) for the provision of environmental data.

634 Additionally, we are grateful to the native English speaker M. Nepf for checking the manuscript. 635 
637

638

639

640

641

642

643

644

645

646

647

648

649

650

651

652

653

654

655

656

657

658

659

660

661

662

663

664

665

666

667

668

669

670

671

672

673

674

675

676

677

678

679

680

681

682

\section{References}

Ackerman JD, Sim B, Nichols SJ, Claudi R. 1994. A review of the early life history of zebra mussels (Dreissena polymorpha): comparisons with marine bivalves. Canadian Journal of Zoology 72:1169-1179. DOI: 10.1139/z94-157.

Balbi T, Fabbri R, Cortese K, Smerilli A, Ciacci C, Grande C, Vezzulli L, Pruzzo C, Canesi L. 2013. Interactions between Mytilus galloprovincialis hemocytes and the bivalve pathogens Vibrio aestuarianus 01/032 and Vibrio splendidus LGP32. Fish and Shellfish Immunology 35:1906-1915. DOI: 10.1016/j.fsi.2013.09.027.

Bartosova A, Capell R, Olesen JE, Jabloun M, Refsgaard JC, Donnelly C, Hyytiäinen K, Pihlainen S, Zandersen M, Arheimer B. 2019. Future socioeconomic conditions may have a larger impact than climate change on nutrient loads to the Baltic Sea. Ambio 48:1325-1336. DOI: $10.1007 / \mathrm{s} 13280-019-01243-5$.

Berthold M, Karsten U, von Weber M, Bachor A, Schumann R. 2018. Phytoplankton can bypass nutrient reductions in eutrophic coastal water bodies. Ambio 47:146-158. DOI: 10.1007/s13280-017-0980-0.

Boesch DF. 2019. Barriers and bridges in abating coastal eutrophication. Frontiers in Marine Science 6:1-25. DOI: 10.3389/fmars.2019.00123.

Borken W, Matzner E. 2009. Reappraisal of drying and wetting effects on C and N mineralization and fluxes in soils. Global Change Biology 15:808-824. DOI: 10.1111/j.1365-2486.2008.01681.x.

Buer A, Maar M, Nepf M, Ritzenhofen L, Dahlke S. 2020a. Potential and Feasibility of Mytilus spp . Farming Along a Salinity Gradient. DOI: 10.3389/fmars.2020.00371.

Buer A-L, Taylor D, Bergström P, Ritzenhofen L, Klemmstein A. 2020b. Nitrogen and Phosphorous Content in Blue Mussels (Mytilus spp.) Across the Baltic Sea. Frontiers in Marine Science 7. DOI: 10.3389/fmars.2020.00705.

Callier MD, Richard M, McKindsey CW, Archambault P, Desrosiers G. 2009. Responses of benthic macrofauna and biogeochemical fluxes to various levels of mussel biodeposition: An in situ "benthocosm" experiment. Marine Pollution Bulletin 58:1544-1553. DOI: 10.1016/j.marpolbul.2009.05.010.

Callol A, Pajuelo D, Ebbesson L, Teles M, MacKenzie S, Amaro C. 2015. Early steps in the European eel (Anguilla anguilla)-Vibrio vulnificus interaction in the gills: Role of the RtxA13 toxin. Fish and Shellfish Immunology 43:502-509. DOI: 10.1016/j.fsi.2015.01.009.

Canesi L, Gallo G, Gavioli M, Pruzzo C. 2002. Bacteria-hemocyte interactions and phagocytosis in marine bivalves. Microscopy Research and Technique 57:469-476. DOI: 10.1002/jemt.10100.

Cavallo RA, Stabili L. 2002. Presence of vibrios in seawater and Mytilus galloprovincialis (Lam.) from the Mar Piccolo of Taranto (Ionian Sea). Water Research 36:3719-3726. DOI: 10.1016/S0043-1354(02)00107-0.

Darr A, Gogina M, Zettler ML. 2014. Detecting hot-spots of bivalve biomass in the southwestern Baltic Sea. Journal of Marine Systems 134:69-80. DOI: 10.1016/j.jmarsys.2014.03.003.

Dumbauld BR, Ruesink JL, Rumrill SS. 2009. The ecological role of bivalve shellfish aquaculture in the estuarine environment: A review with application to oyster and clam

Peer) reviewing PDF | (2020:10:53759:1:2:NEW 10 Mar 2021) 
683

684

685

686

687

688

689

690

691

692

693

694

695

696

697

698

699

700

701

702

703

704

705

706

707

708

709

710

711

712

713

714

715

716

717

718

719

720

721

722

723

724

725

726

727

728

culture in West Coast (USA) estuaries. Aquaculture 290:196-223. DOI:

10.1016/j.aquaculture.2009.02.033.

Fenske C. 2005. Renaturierung von Gewässern mit Hilfe der Wandermuschel Dreissena polymorpha (Pallas, 1771). Rostock. Meeresbiolog. Beitr. 14:55-68.

Ferreira JG, Bricker SB. 2016. Goods and services of extensive aquaculture: shellfish culture and nutrient trading. Aquaculture International 24:803-825. DOI: 10.1007/s10499-015-9949-9.

Friedland R, Buer AL, Dahlke S, Schernewski G. 2019a. Spatial effects of different zebra mussel farming strategies in an eutrophic Baltic Lagoon. Frontiers in Environmental Science 6. DOI: 10.3389/fenvs.2018.00158.

Friedland R, Schernewski G, Gräwe U, Greipsland I, Palazzo D, Pastuszak M. 2019b. Managing eutrophication in the Szczecin (Oder) lagoon-development, present state and future perspectives. Frontiers in Marine Science 5:1-17. DOI: 10.3389/fmars.2018.00521.

Giles H, Broekhuizen N, Bryan KR, Pilditch CA. 2009. Modelling the dispersal of biodeposits from mussel farms: The importance of simulating biodeposit erosion and decay. Aquaculture 291:168-178. DOI: 10.1016/j.aquaculture.2009.03.010.

Giles H, Pilditch CA, Bell DG. 2006. Sedimentation from mussel (Perna canaliculus) culture in the Firth of Thames, New Zealand: Impacts on sediment oxygen and nutrient fluxes. Aquaculture 261:125-140. DOI: 10.1016/j.aquaculture.2006.06.048.

Gren I-M, Jonzon Y, Lindqvist M. 2008. Costs of nutrient reductions to the Baltic Sea- technical. $: 1-64$.

Gyraite G, Katarzyte M, Schernewski G. 2019. First findings of potentially human pathogenic bacteria Vibrio in the south-eastern Baltic Sea coastal and transitional bathing waters. Marine Pollution Bulletin 149:110546. DOI: 10.1016/j.marpolbul.2019.110546.

Hautakangas S, Ollikainen M, Aarnos K, Rantanen P. 2014. Nutrient abatement potential and abatement costs of waste water treatment plants in the Baltic Sea region. Ambio 43:352360. DOI: $10.1007 / \mathrm{s} 13280-013-0435-1$.

Holbach A, Maar M, Timmermann K, Taylor D. 2020. A spatial model for nutrient mitigation potential of blue mussel farms in the western Baltic Sea. Science of the Total Environment 736:139624. DOI: 10.1016/j.scitotenv.2020.139624.

Ina-Salwany MY, Al-saari N, Mohamad A, Mursidi FA, Mohd-Aris A, Amal MNA, Kasai H, Mino S, Sawabe T, Zamri-Saad M. 2019. Vibriosis in Fish: A Review on Disease Development and Prevention. Journal of Aquatic Animal Health 31:3-22. DOI: 10.1002/aah.10045.

Jacob D, Göttel H, Kotlarski S, Lorenz P, Sieck K. 2008. Klimaauswirkungen und Anpassung in Deutschland-Phase 1: Erstellung regionaler Klimaszenarien für Deutschland. Climate Change 11:154. DOI: 10.1038/480032a.

Karstens S, Nazzari C, Bâlon C, Bielecka M, Grigaitis Ž, Schumacher J, Stybel N, RazinkovasBaziukas A. 2018. Floating wetlands for nutrient removal in eutrophicated coastal lagoons: Decision support for site selection and permit process. Marine Policy 97:51-60. DOI: 10.1016/j.marpol.2018.08.030.

Kotta J, Futter M, Kaasik A, Liversage K, Rätsep M, Barboza FR, Bergström L, Bergström P, Bobsien I, Díaz E, Herkül K, Jonsson PR, Korpinen S, Kraufvelin P, Krost P, Lindahl O, Lindegarth M, Lyngsgaard MM, Mühl M, Sandman AN, Orav-Kotta H, Orlova M, Skov H, Rissanen J, Šiaulys A, Vidakovic A, Virtanen E. 2020a. Cleaning up seas using blue growth initiatives: Mussel farming for eutrophication control in the Baltic Sea. Science of the Total Environment 709. DOI: 10.1016/j.scitotenv.2019.136144. 
729

730

731

732

733

734

735

736

737

738

739

740

741

742

743

744

745

746

747

748

749

750

751

752

753

754

755

756

757

758

759

760

761

762

763

764

765

766

767

768

769

770

771

772

773

774

Kotta J, Futter M, Kaasik A, Liversage K, Rätsep M, Barboza FR, Bergström L, Bergström P, Bobsien I, Díaz E, Herkül K, Jonsson PR, Korpinen S, Kraufvelin P, Krost P, Lindahl O, Lindegarth M, Lyngsgaard MM, Mühl M, Sandman AN, Orav-Kotta H, Orlova M, Skov H, Rissanen J, Šiaulys A, Vidakovic A, Virtanen E. 2020b. Response to a letter to editor regarding Kotta et al. 2020: Cleaning up seas using blue growth initiatives: Mussel farming for eutrophication control in the Baltic Sea. Science of the Total Environment 739:138712. DOI: $10.1016 /$ j.scitotenv.2020.138712.

Krost P, Rehm S, Kock M, Piker L. 2011. Leitfaden für nachhaltige marine Aquakultur. :63.

Larsson J, Lind EE, Corell H, Grahn M, Smolarz K, Lönn M. 2017. Regional genetic differentiation in the blue mussel from the Baltic Sea area. Estuarine, Coastal and Shelf Science 195:98-109. DOI: 10.1016/j.ecss.2016.06.016.

Lindahl O. 2012. Mussel Farming as an Environmental Measure in the Baltic. BalticSea2020:19. Lindahl O, Hart R, Hernroth B, Kollberg S, Loo LO, Olrog L, Rehnstam-Holm a S, Svensson J, Svensson S, Syversen U. 2005. Improving marine water quality by mussel farming: A profitable solution for Swedish society. AMBIO: A Journal of the Human Environment 34:131-138. DOI: 10.1639/0044-7447(2005)034[0131:imwqbm]2.0.co;2.

Lindahl O, Kollberg S. 2008. How mussels can improve coastal water quality: Mussel farming a way to combat eutrophication. Bioscience | Explained 5:1-14.

Maar M, Saurel C, Landes A, Dolmer P, Petersen JK. 2015. Growth potential of blue mussels (M. edulis) exposed to different salinities evaluated by a Dynamic Energy Budget model. Journal of Marine Systems 148:48-55. DOI: 10.1016/j.jmarsys.2015.02.003.

Metelmann C, Metelmann B, Gründling M, Hahnenkamp K, Hauk G, Scheer C. 2020. Vibrio vulnificus, an increasing threat of sepsis in Germany? Anaesthesist 69:672-678. DOI: 10.1007/s00101-020-00811-9.

Munkes B. 2005. Eutrophication, phase shift, the delay and the potential return in the Greifswalder Bodden, Baltic Sea. Aquatic Sciences 67:372-381. DOI: 10.1007/s00027-0050761-x.

Naylor RL, Williams SL, Strong DR. 2001. Aquaculture - A gateway for exotic species. Science 294:1655-1656. DOI: 10.1126/science.1064875.

Newcomb LA, George MN, O’Donnell MJ, Carrington E. 2019. Only as strong as the weakest link: Structural analysis of the combined effects of elevated temperature and $\mathrm{pCO} 2$ on mussel attachment. Conservation Physiology 7:1-11. DOI: 10.1093/conphys/coz068.

Nielsen SL, Sand-Jensen K, Borum J, Geertz-Hansen O. 2002. Phytoplankton, nutrients, and transparency in Danish coastal waters. Estuaries 25:930-937. DOI: 10.1007/BF02691341.

Nizzoli D, Welsh DT, Bartoli M, Viaroli P. 2005. Impacts of mussel (Mytilus galloprovincialis) farming on oxygen consumption and nutrient recycling in a eutrophic coastal lagoon. Hydrobiologia 550:183-198. DOI: 10.1007/s10750-005-4378-9.

Petersen JK, Hasler B, Timmermann K, Nielsen P, Tørring DB, Larsen MM, Holmer M. 2014. Mussels as a tool for mitigation of nutrients in the marine environment. Marine Pollution Bulletin 82:137-143. DOI: 10.1016/j.marpolbul.2014.03.006.

Petersen J, Loo L, Taylor D. 2019. Evaluating chlorophyll depletion in mitigation mussel cultivation at multiple scales. Aquaculture Environment Interactions 11:263-278. DOI: 10.3354/aei00312.

Potasman I, Paz A, Odeh M. 2002. Infectious outbreaks associated with bivalve shellfish consumption: A worldwide perspective. Clinical Infectious Diseases 35:921-928. DOI: $10.1086 / 342330$. 
775

776

777

778

779

780

781

782

783

784

785

786

787

788

789

790

791

792

793

794

795

796

797

798

799

800

801

802

803

804

805

806

807

808

809

810

811

812

813

814

815

816

817

818

819

820

Rahman MA, Henderson S, Miller-Ezzy P, Li XX, Qin JG. 2019. Immune response to temperature stress in three bivalve species: Pacific oyster Crassostrea gigas, Mediterranean mussel Mytilus galloprovincialis and mud cockle Katelysia rhytiphora. Fish and Shellfish Immunology 86:868-874. DOI: 10.1016/j.fsi.2018.12.017.

Richard M, Archambault P, Thouzeau G, Desrosiers G. 2007. Summer influence of 1 and 2 yr old mussel cultures on benthic fluxes in Grande-Entrée lagoon, Îles-de-la-Madeleine (Québec, Canada). Marine Ecology Progress Series 338:131-143. DOI: 10.3354/meps338131.

Riisgard HU. 1991. Filtration Rate and Growth in the Blue Mussel, Mytilus Edllis Linneaus. 1758: Dependence on Algal Concentration. Journal of Shellfish Research 10:29-35.

Riisgård HU, Bøttiger L, Pleissner D. 2012. Effect of Salinity on Growth of Mussels, \&lt;i\&gt;Mytilus edulis\&lt;/i\&gt; with Special Reference to Great Belt (Denmark). Open Journal of Marine Science 02:167-176. DOI: 10.4236/ojms.2012.24020.

Riisgård HU, Kittner C, Seerup DF. 2003. Regulation of opening state and filtration rate in filterfeeding bivalves (Cardium edule, Mytilus edulis, Mya arenaria) in response to low algal concentration. Journal of Experimental Marine Biology and Ecology 284:105-127. DOI: 10.1016/S0022-0981(02)00496-3.

Rincé A, Balière C, Hervio-Heath D, Cozien J, Lozach S, Parnaudeau S, Le Guyader FS, Le Hello S, Giard JC, Sauvageot N, Benachour A, Strubbia S, Gourmelon M. 2018. Occurrence of bacterial pathogens and human noroviruses in shellfish- Harvesting areas and their catchments in France. Frontiers in Microbiology 9:1-17. DOI: 10.3389/fmicb.2018.02443.

Ruppert J, Panzig B, Guertler L, Hinz P, Schwesinger G, Felix SB, Friesecke S. 2004. Two cases of severe sepsis due to Vibrio vulnificus wound infection acquired in the Baltic Sea. European Journal of Clinical Microbiology and Infectious Diseases 23:912-915. DOI: 10.1007/s10096-004-1241-2.

Rydin E, Kumblad L, Wulff F, Larsson P. 2017. Remediation of a Eutrophic Bay in the Baltic Sea. Environmental Science and Technology 51:4559-4566. DOI: 10.1021/acs.est.6b06187. Schernewski G, Friedland R, Carstens M, Hirt U, Leujak W, Nausch G, Neumann T, Petenati T, Sagert S, Wasmund N, Weber M Von. 2015. Implementation of European marine policy : New water quality targets for German Baltic waters. Marine Policy 51:305-321. DOI: 10.1016/j.marpol.2014.09.002.

Schernewski G, Stybel N, Neumann T. 2012. Zebra mussel farming in the Szczecin (Oder) Lagoon: Water-quality objectives and cost-effectiveness. Ecology and Society 17. DOI: 10.5751/ES-04644-170204.

Schernewski G, Wielgat M, Christiansen T, Wulff F, Witek Z. 2004. A Baltic Sea typology according to the EC-Water Framework Directive : Integration of national typologies and the water body concept with contributions from CHARM partners : Bjorn Sjoberg, Tobias Dolch, Andris. 4:1-26.

Schiele KS, Darr A, Zettler ML. 2014. Verifying a biotope classification using benthic communities - An analysis towards the implementation of the European Marine Strategy Framework Directive. Marine Pollution Bulletin 78:181-189. DOI: 10.1016/j.marpolbul.2013.10.045.

Schiele KS, Darr A, Zettler ML, Friedland R, Tauber F, von Weber M, Voss J. 2015. Biotope map of the German Baltic Sea. Marine Pollution Bulletin 96:127-135. DOI: 10.1016/j.marpolbul.2015.05.038. 
821 Schiewer U. 1997. 30 years' eutrophication in shallow brackish waters - Lessons to be learned.

822

823

824

825

826

827

828

829

830

831

832

833

834

835

836

837

838

839

840

841

842

843

844

845

846

847

848

849

850

851

852

853

854

855

856

857

858

859

860

861

862

863

864

865

866 Hydrobiologia 363:73-79. DOI: 10.1023/A:1003194226294.

Schröder T, Stank J, Schernewski G, Krost P. 2014. The impact of a mussel farm on water transparency in the Kiel Fjord. Ocean and Coastal Management 101:42-52. DOI: 10.1016/j.ocecoaman.2014.04.034.

Schulte EH. 1975. Influence of algal concentration and temperature on the filtration rate of Mytilus edulis. Marine Biology 30:331-341. DOI: 10.1007/BF00390638.

Schumann R, Baudler H, Glass Ä, Dümcke K, Karsten U. 2006. Long-term observations on salinity dynamics in a tideless shallow coastal lagoon of the Southern Baltic Sea coast and their biological relevance. Journal of Marine Systems 60:330-344. DOI: 10.1016/j.jmarsys.2006.02.007.

Selig U, Baudler H, Krech M, Nausch G. 2006. Nutrient accumulation and nutrient retention in coastal waters - 30 years investigation in the Darss-Zingst Bodden chain. Acta Hydrochimica et Hydrobiologica 34:9-19. DOI: 10.1002/aheh.200500616.

Soon TK, Denil DJ, Ransangan J. 2016. High mortality and poor growth of green mussels, Perna viridis, in high chlorophyll-a environment. Ocean Science Journal 51:43-57. DOI: 10.1007/s12601-016-0005-0.

Spekat A, Enke W, Kreienkamp F. 2007. Neuentwicklung von regional hoch aufgelösten Wetterlagen für Deutschland und Bereitstellung regionaler Klimaszenarios auf der Basis von globalen Klimasimulationen mit dem Regionalisierungsmodell WETTREG auf der Basis von globalen Klimasimulationen. Umwelt Bundes Amt:149.

Stabili L, Acquaviva MI, Cavallo RA. 2005. Mytilus galloprovincialis filter feeding on the bacterial community in a Mediterranean coastal area (Northern Ionian Sea, Italy). Water Research 39:469-477. DOI: 10.1016/j.watres.2004.10.010.

Stadmark J, Conley DJ. 2011. Mussel farming as a nutrient reduction measure in the Baltic Sea: Consideration of nutrient biogeochemical cycles. Marine Pollution Bulletin 62:1385-1388. DOI: 10.1016/j.marpolbul.2011.05.001.

Stigebrandt A, Liljebladh B, de Brabandere L, Forth M, Granmo Å, Hall P, Hammar J, Hansson D, Kononets M, Magnusson M, Norén F, Rahm L, Treusch AH, Viktorsson L. 2014. An Experiment with Forced Oxygenation of the Deepwater of the Anoxic By Fjord, Western Sweden. Ambio 44:42-54. DOI: 10.1007/s13280-014-0524-9.

Stybel N, Fenske C, Schernewski G. 2009. Mussel Cultivation to Improve Water Quality in the Szczecin Lagoon. Journal of Coastal Research 2009:1459-1463.

Tanguy M, McKenna P, Gauthier-Clerc S, Pellerin J, Danger JM, Siah A. 2013. Functional and molecular responses in Mytilus edulis hemocytes exposed to bacteria, Vibrio splendidus. Developmental and Comparative Immunology 39:419-429. DOI: 10.1016/j.dci.2012.10.015.

Taylor D, Saurel C, Nielsen P, Petersen JK. 2019. Production Characteristics and Optimization of Mitigation Mussel Culture. Frontiers in Marine Science 6:1-17. DOI: 10.3389/fmars.2019.00698.

Timmermann K, Maar M, Bolding K, Larsen J, Windolf J, Nielsen P, Petersen J. 2019. Mussel production as a nutrient mitigation tool for improving marine water quality. Aquaculture Environment Interactions 11:191-204. DOI: 10.3354/aei00306.

UBA. 2017. Gewässer in Deutschland : Zustand und Bewertung. Bundesministerium für Umwelt, Naturschutz, Bau Und Reaktorsicherheit:132.

Weise AM, Cromey CJ, Callier MD, Archambault P, Chamberlain J, McKindsey CW. 2009.

Peer) reviewing PDF | (2020:10:53759:1:2:NEW 10 Mar 2021) 
867 Shellfish-DEPOMOD: Modelling the biodeposition from suspended shellfish aquaculture 868 and assessing benthic effects. Aquaculture 288:239-253. DOI:

$869 \quad 10.1016 /$ j.aquaculture.2008.12.001.

870

871

872

873

874

875

876

877

878

879

880

881

882

883

884

885

Westerbom M, Kilpi M, Mustonen O. 2002. Blue mussels, Mytilus edulis at the edge of the range: population structure, growth and biomass along a salinity gradient in the northeastern Baltic Sea. Marine Biology 140:991-999. DOI: DOI 10.1007/s00227-001-0765-6.

WFD CIS. 2003. Common Implementation Strategy for the Water Framework Directive ( 2000 / $60 /$ EC) Guidance document $n .{ }^{\circ} 1$ Economics and the environment - The Implementation Challenge of the Water Framework Directive. DOI: 10.2779/53333.

Wikström SA, Hedberg N, Kautsky N, Kumblad L, Ehrnsten E, Gustafsson B, Humborg C, Norkko A, Stadmark J. 2020. Letter to editor regarding Kotta et al. 2020: Cleaning up seas using blue growth initiatives: Mussel farming for eutrophication control in the Baltic Sea. Science of the Total Environment 727:138665. DOI: 10.1016/j.scitotenv.2020.138665.

Wiles PJ, van Duren LA, Häse C, Larsen J, Simpson JH. 2006. Stratification and mixing in the Limfjorden in relation to mussel culture. Journal of Marine Systems 60:129-143. DOI: 10.1016/j.jmarsys.2005.09.009.

Williges K, Mechler R, Bowyer P, Balkovic J. 2017. Towards an assessment of adaptive capacity of the European agricultural sector to droughts. Climate Services 7:47-63. DOI:

886 


\section{Table 1 (on next page)}

Main characteristics of the investigated coastal water bodies.

Data for surface area, water depth, salinity and water exchange are extracted from Schiewer (2007) and Schlungbaum \& Baulder (2001). 
1

\begin{tabular}{lcccc}
\hline Water body & $\begin{array}{c}\text { Area } \\
{\left[\mathrm{km}^{2}\right]}\end{array}$ & $\begin{array}{c}\text { Mean depth } \\
{[\mathrm{m}]}\end{array}$ & $\begin{array}{c}\text { Salinity } \\
{[\mathrm{PSU}]}\end{array}$ & $\begin{array}{c}\text { Water exchange } \\
\text { rate }\left[\mathrm{a}^{-1}\right]\end{array}$ \\
\hline Wismar Bay & 170 & 5.5 & 11 & 0.01 \\
Salzhaff & 21 & 2.3 & 11 & 0.01 \\
Unterwarnow & 12.5 & 4 & 12 & 0.03 \\
Barther Bodden & 19.4 & 1.6 & 7 & 0.13 \\
$\begin{array}{l}\text { Strelasund } \\
\text { Westrügenscher }\end{array}$ & 64.4 & 3.9 & 10 & 0.04 \\
$\begin{array}{l}\text { Bodden } \\
\text { Greifswalder }\end{array}$ & 171.3 & 1.8 & 10 & 0.14 \\
$\begin{array}{l}\text { Bodden } \\
\text { Kleiner }\end{array}$ & 514 & 5.8 & 7.5 & 0.1 \\
$\begin{array}{l}\text { Jasmunder } \\
\text { Bodden }\end{array}$ & 28.4 & 2.8 & & \\
Nordrügenscher & 124 & 3.5 & 9 & 0.14 \\
Bodden & & & & 0.14 \\
\hline \hline
\end{tabular}

2 


\section{Table 2(on next page)}

Seasonal dissolved inorganic nitrogen (DIN), phosphorus (DIP) and Chl.a. concentration in the different water bodies of the study site.

(A) Spring $=$ March-April. (B) Summer $=$ May-September. (C) Fall $=$ October-November. DIN:

DIP ratios indicate limitation of either nitrogen (bold numbers) or phosphorus (italic numbers). 


\begin{tabular}{|c|c|c|c|c|c|c|c|c|c|c|c|c|c|c|c|c|c|c|c|c|}
\hline \multirow{3}{*}{ A } & \multicolumn{8}{|c|}{ Spring } & & & & & & & & & & & & \\
\hline & \multicolumn{4}{|c|}{ March } & \multicolumn{4}{|c|}{ April } & & & & & & & & & & & & \\
\hline & $\begin{array}{c}\mathrm{DIN} \\
{[\mu \mathrm{mol} / 1]}\end{array}$ & $\begin{array}{c}\text { DIP } \\
{[\mu \mathrm{mol} / 1]}\end{array}$ & $\begin{array}{l}\text { DIN/ } \\
\text { DIP }\end{array}$ & $\begin{array}{c}\text { Chl.a } \\
{\left[\mathrm{mg} \mathrm{m}^{-3}\right]}\end{array}$ & $\begin{array}{c}\mathrm{DIN} \\
{[\mu \mathrm{mol} / 1]}\end{array}$ & $\begin{array}{c}\text { DIP } \\
{[\mu \mathrm{mol} / 1]}\end{array}$ & $\begin{array}{l}\text { DIN/ } \\
\text { DIP }\end{array}$ & $\begin{array}{c}\mathrm{Chl} . \mathrm{a} \\
{\left[\mathrm{mg} \mathrm{m}^{-3}\right]}\end{array}$ & & & & & & & & & & & & \\
\hline Wismar Bay & 9.94 & 0.36 & 27 & 8.39 & 2.28 & 0.15 & 16 & 1.49 & & & & & & & & & & & & \\
\hline Salzhaff & 73.85 & 0.23 & 325 & 7.36 & 34.63 & 0.09 & 391 & 2.42 & & & & & & & & & & & & \\
\hline $\begin{array}{l}\text { Warnow } \\
\text { Estuary }\end{array}$ & 117.36 & 0.60 & 196 & 6.63 & 40.70 & 0.35 & 116 & 7.16 & & & & & & & & & & & & \\
\hline $\begin{array}{l}\text { Barther } \\
\text { Bodden }\end{array}$ & 92.87 & 0.13 & 720 & 36.19 & 26.44 & 0.12 & 212 & 77.68 & & & & & & & & & & & & \\
\hline $\begin{array}{l}\text { West } \\
\text { Ruegenscher } \\
\text { Bodden }\end{array}$ & 26.76 & 0.40 & 68 & 7.44 & 4.16 & 0.16 & 26 & 8.38 & & & & & & & & & & & & \\
\hline Strelasund & 16.60 & 0.10 & 159 & 19.36 & 8.85 & 0.09 & 93 & 12.03 & & & & & & & & & & & & \\
\hline $\begin{array}{l}\text { Greifswalder } \\
\text { Bodden }\end{array}$ & 26.70 & 0.11 & 249 & 39.59 & 10.24 & 0.10 & 103 & 18.97 & & & & & & & & & & & & \\
\hline $\begin{array}{l}\text { Kleiner } \\
\text { Jasmunder } \\
\text { Bodden }\end{array}$ & 40.88 & 0.20 & 209 & 76.49 & 9.34 & 0.26 & 36 & 111.44 & & & & & & & & & & & & \\
\hline \multirow[t]{4}{*}{$\begin{array}{l}\text { Nord } \\
\text { Ruegenscher } \\
\text { Bodden } \\
\end{array}$} & 13.70 & 0.14 & 101 & 15.30 & 5.55 & 0.08 & 67 & 19.60 & & & & & & & & & & & & \\
\hline & \multicolumn{20}{|c|}{ Summer } \\
\hline & \multicolumn{4}{|c|}{ May } & \multicolumn{4}{|c|}{ June } & \multicolumn{4}{|c|}{ July } & \multicolumn{4}{|c|}{ August } & \multicolumn{4}{|c|}{ September } \\
\hline & $\begin{array}{c}\mathrm{DIN} \\
{[\mu \mathrm{mol} / 1]}\end{array}$ & $\begin{array}{c}\text { DIP } \\
{[\mu \mathrm{mol} / 1]}\end{array}$ & $\begin{array}{l}\text { DIN/ } \\
\text { DIP }\end{array}$ & $\begin{array}{c}\text { Chl.a } \\
{\left[\mathrm{mg} \mathrm{m}^{-3}\right]}\end{array}$ & $\begin{array}{c}\mathrm{DIN} \\
{[\mu \mathrm{mol} / 1]}\end{array}$ & $\begin{array}{c}\text { DIP } \\
{[\mu \mathrm{mol} / 1]}\end{array}$ & $\begin{array}{l}\text { DIN/ } \\
\text { DIP }\end{array}$ & $\begin{array}{c}\text { Chl.a } \\
{\left[\mathrm{mg} \mathrm{m}^{-3}\right]}\end{array}$ & $\begin{array}{c}\mathrm{DIN} \\
{[\mu \mathrm{mol} / 1]}\end{array}$ & $\begin{array}{c}\text { DIP } \\
{[\mu \mathrm{mol} / 1]}\end{array}$ & $\begin{array}{l}\text { DIN/ } \\
\text { DIP }\end{array}$ & $\begin{array}{c}\text { Chl.a } \\
{\left[\mathrm{mg} \mathrm{m}^{-3}\right]}\end{array}$ & $\begin{array}{c}\mathrm{DIN} \\
{[\mu \mathrm{mol} / 1]}\end{array}$ & $\begin{array}{c}\text { DIP } \\
{[\mu \mathrm{mol} / 1]}\end{array}$ & $\begin{array}{l}\text { DIN/ } \\
\text { DIP }\end{array}$ & $\begin{array}{l}\text { Chl.a } \\
{\left[\mathrm{mg} \mathrm{m}^{-3}\right]}\end{array}$ & $\begin{array}{c}\text { DIN } \\
{[\mu \mathrm{mol} / 1]}\end{array}$ & $\begin{array}{c}\text { DIP } \\
{[\mu \mathrm{mol} / 1]}\end{array}$ & $\begin{array}{l}\text { DIN/ } \\
\text { DIP }\end{array}$ & $\begin{array}{c}\text { Chl.a } \\
{\left[\mathrm{mg} \mathrm{m}^{-3}\right]}\end{array}$ \\
\hline Wismar Bay & 1.07 & 0.10 & 11 & 1.31 & 0.79 & 0.23 & 3 & 2.18 & 0.71 & 0.28 & 3 & 4.68 & 1.12 & 0.54 & 2 & 4.68 & 2.11 & 0.57 & 4 & 5.86 \\
\hline Salzhaff & 2.25 & 0.09 & 26 & 2.63 & 1.30 & 0.58 & 2 & 2.30 & 2.04 & 1.09 & 2 & 5.00 & 15.69 & 1.25 & 13 & 14.71 & 8.49 & 0.57 & 15 & 10.42 \\
\hline $\begin{array}{l}\text { Warnow } \\
\text { Estuary }\end{array}$ & 9.41 & 0.18 & 53 & 9.17 & 3.52 & 0.47 & 7 & 14.01 & 7.06 & 0.65 & 11 & 13.18 & 12.66 & 0.91 & 14 & 7.50 & 10.24 & 1.14 & 9 & 7.11 \\
\hline $\begin{array}{l}\text { Barther } \\
\text { Bodden }\end{array}$ & 4.15 & 0.16 & 25 & 69.53 & 1.35 & 0.14 & 10 & 51.42 & 1.46 & 0.13 & 11 & 37.11 & 5.91 & 0.17 & 36 & 56.34 & 2.56 & 0.12 & 21 & 59.31 \\
\hline $\begin{array}{l}\text { West } \\
\text { Ruegenscher } \\
\text { Bodden } \\
\end{array}$ & 1.83 & 0.10 & 19 & 7.42 & 1.47 & 0.16 & 9 & 9.65 & 1.16 & 0.21 & 5 & 9.65 & 1.24 & 0.18 & 7 & 12.28 & 0.96 & 0.14 & 7 & 7.60 \\
\hline Strelasund & 2.12 & 0.09 & 23 & 14.74 & 1.81 & 0.14 & 13 & 17.84 & 0.84 & 0.26 & 3 & 16.48 & 0.77 & 0.26 & 3 & 24.40 & 1.78 & 0.46 & 4 & 16.78 \\
\hline $\begin{array}{l}\text { Greifswalder } \\
\text { Bodden }\end{array}$ & 4.79 & 0.09 & 55 & 14.00 & 2.23 & 0.14 & 16 & 14.80 & 1.39 & 0.24 & 6 & 16.71 & 1.19 & 0.70 & 2 & 23.59 & 1.75 & 0.50 & 4 & 20.37 \\
\hline $\begin{array}{l}\text { Kleiner } \\
\text { Jasmunder } \\
\text { Bodden } \\
\end{array}$ & 2.07 & 0.34 & 6 & 111.44 & 4.13 & 0.31 & 13 & 90.81 & 1.85 & 0.18 & 10 & 67.27 & 2.00 & 0.15 & 13 & 70.08 & 4.41 & 0.31 & 14 & 83.21 \\
\hline
\end{tabular}




\begin{tabular}{|c|c|c|c|c|c|c|c|c|c|c|c|c|c|c|c|c|c|c|c|c|}
\hline $\begin{array}{l}\text { Nord } \\
\text { Ruegenscher } \\
\text { Bodden }\end{array}$ & 1.52 & 0.09 & 16 & 18.44 & 1.17 & 0.14 & 9 & 19.77 & 1.05 & 0.11 & 9 & 21.56 & 1.47 & 0.21 & 7 & 24.62 & 1.27 & 0.25 & 5 & 19.45 \\
\hline \multirow{3}{*}{ C } & \multicolumn{8}{|c|}{ Fall } & & & & & & & & & & & & \\
\hline & \multicolumn{4}{|c|}{ October } & \multicolumn{4}{|c|}{ November } & & & & & & & & & & & & \\
\hline & $\begin{array}{c}\text { DIN } \\
{[\mu \mathrm{mol} / 1]}\end{array}$ & $\underset{[\mu \mathrm{mol} / 1]}{\mathrm{DIP}}$ & $\begin{array}{l}\text { DIN/ } \\
\text { DIP }\end{array}$ & $\underset{\left[\mathrm{mg} \mathrm{m}^{-3}\right]}{\mathrm{Chl} . \mathrm{a}}$ & $\begin{array}{c}\text { DIN } \\
{[\mu \mathrm{mol} / 1]}\end{array}$ & $\left.\begin{array}{c}\mathrm{DIP} \\
{[\mu \mathrm{mol} / 1]}\end{array}\right]$ & $\begin{array}{l}\text { DIN/ } \\
\text { DIP }\end{array}$ & $\begin{array}{c}\text { Chl.a } \\
{\left[\mathrm{mg} \mathrm{m}^{-3}\right]}\end{array}$ & & & & & & & & & & & & \\
\hline Wismar Bay & 1.41 & 0.34 & 4 & 3.68 & 5.39 & 0.55 & 10 & 3.17 & & & & & & & & & & & & \\
\hline Salzhaff & 8.59 & 0.20 & 44 & 6.13 & 30.67 & 0.19 & 159 & 4.73 & & & & & & & & & & & & \\
\hline $\begin{array}{l}\text { Warnow } \\
\text { Estuary }\end{array}$ & 5.51 & 0.75 & 7 & 2.75 & 35.56 & 1.03 & 34 & 2.86 & & & & & & & & & & & & \\
\hline $\begin{array}{l}\text { Barther } \\
\text { Bodden }\end{array}$ & 2.14 & 0.12 & 18 & 57.22 & 17.32 & 0.18 & 96 & 49.62 & & & & & & & & & & & & \\
\hline $\begin{array}{l}\text { West } \\
\text { Ruegenscher } \\
\text { Bodden }\end{array}$ & 2.27 & 0.25 & 9 & 6.33 & 4.16 & 0.21 & 20 & 9.40 & & & & & & & & & & & & \\
\hline Strelasund & 3.13 & 0.30 & 10 & 15.36 & 5.81 & 0.32 & 18 & 19.13 & & & & & & & & & & & & \\
\hline $\begin{array}{l}\text { Greifswalder } \\
\text { Bodden }\end{array}$ & 4.79 & 0.55 & 9 & 18.77 & 4.91 & 0.52 & 9 & 15.08 & & & & & & & & & & & & \\
\hline $\begin{array}{l}\text { Kleiner } \\
\text { Jasmunder } \\
\text { Bodddn }\end{array}$ & 5.76 & 0.16 & 36 & 96.62 & 27.31 & 0.12 & 219 & 73.16 & & & & & & & & & & & & \\
\hline $\begin{array}{l}\text { Nord } \\
\text { Ruegenscher } \\
\text { Bodden }\end{array}$ & 2.34 & 0.16 & 15 & 15.51 & 3.62 & 0.16 & 23 & 11.63 & & & & & & & & & & & & \\
\hline
\end{tabular}




\section{Table 3(on next page)}

Reduction of TN concentration by mussel farming and associated water transparency improvement in summer (Aug/Sept).

For the Hagensche Wiek, monthly reduction of nitrogen and increase in Secchi depth were added together, because of its water exchange rate of 6-7 $a^{-1}$. 


\begin{tabular}{|c|c|c|c|c|c|c|c|}
\hline \multirow[t]{2}{*}{ Water body } & \multirow[t]{2}{*}{$\begin{array}{l}\text { Farm size } \\
{[\% \text { of the }} \\
\text { water body } \\
\text { surface }]\end{array}$} & \multicolumn{2}{|c|}{$\begin{array}{l}\text { Nitrogen retention } \\
\text { by mussel growth }[\mathrm{t}]\end{array}$} & \multicolumn{2}{|c|}{ 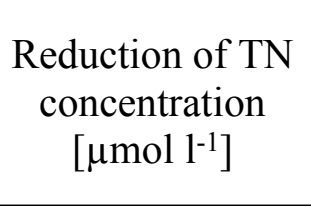 } & \multicolumn{2}{|c|}{$\begin{array}{c}\text { Secchi depth } \\
\text { improvement by } \\
\text { nitrogen retention } \\
{[\mathrm{cm}]}\end{array}$} \\
\hline & & Aug. & Sept. & Aug. & Sept. & Aug. & Sept. \\
\hline \multirow{4}{*}{ GWB } & 1 & 0.5 & 5.1 & 40.7 & 40.6 & 0.64 & 0.50 \\
\hline & 10 & 5.1 & 51.4 & 40.6 & 39.5 & 0.71 & 1.18 \\
\hline & 25 & 12.9 & 128.5 & 40.5 & 37.7 & 0.85 & 3.51 \\
\hline & 50 & 25.7 & 257.0 & 40.2 & 34.6 & 1.13 & 7.83 \\
\hline \multirow{4}{*}{$\begin{array}{l}\text { Hagensche } \\
\text { Wiek }\end{array}$} & 1 & 0.0 & 0.1 & \multicolumn{2}{|c|}{39.8} & \multicolumn{2}{|c|}{0.8} \\
\hline & 10 & 0.1 & 1.3 & \multicolumn{2}{|c|}{38.4} & \multicolumn{2}{|c|}{1.66} \\
\hline & 25 & 0.3 & 3.1 & \multicolumn{2}{|c|}{36.1} & \multicolumn{2}{|c|}{5.9} \\
\hline & 50 & 0.6 & 6.3 & \multicolumn{2}{|c|}{32.1} & \multicolumn{2}{|c|}{10.6} \\
\hline
\end{tabular}


Figure 1

Map of the study site.

Mesohaline inner coastal water bodies (blue areas, labeled in red) including monitoring stations of the State Agency for Environment, Nature Conservation and Geology Mecklenburg-Vorpommern (LUNG) (red dots) providing environmental data for every water body in the study area (where multiple measuring stations occur, data of these stations are pooled (marked by a dotted line)). Green dots represent the two pilot mussel farms.

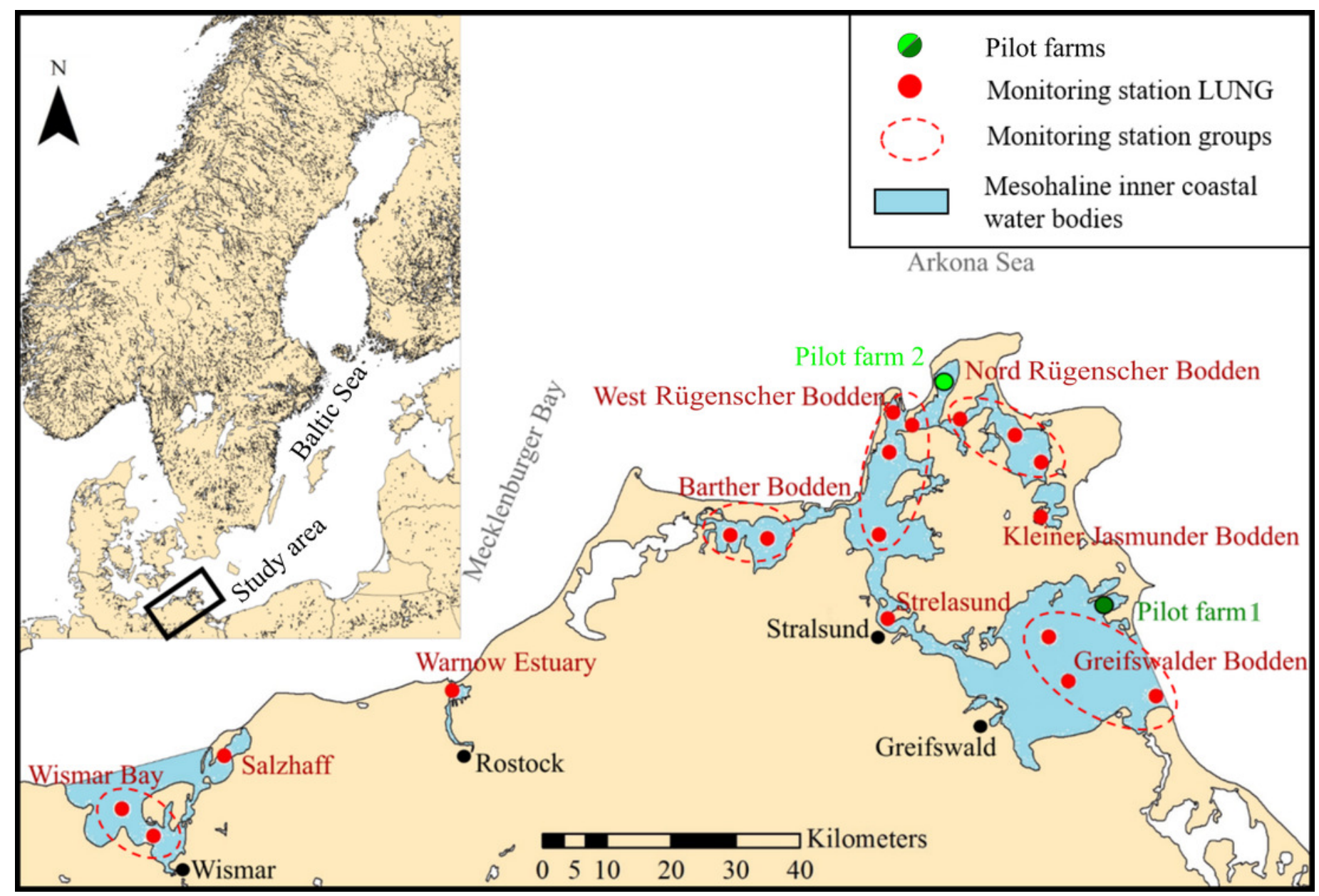




\section{Figure 2}

Design of the two pilot longline mussel farms located in GWB and Wieker Bay.

(A) Pilot farm 1 located in GWB. (B) Pilot farm 2 located in Wieker Bay. Credits: Lukas

Ritzenhofen, Sven Dahlke

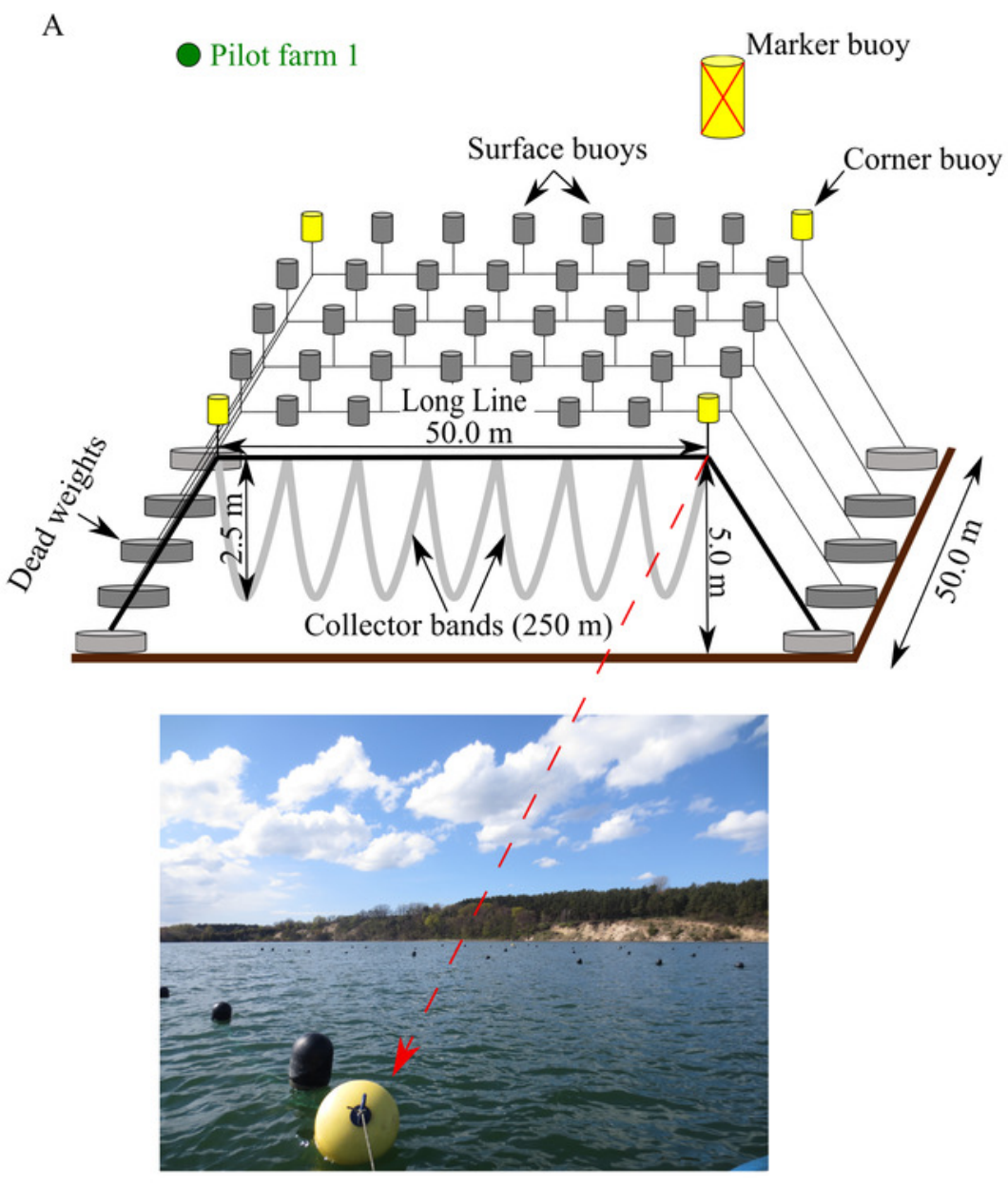

B

Pilot farm 2

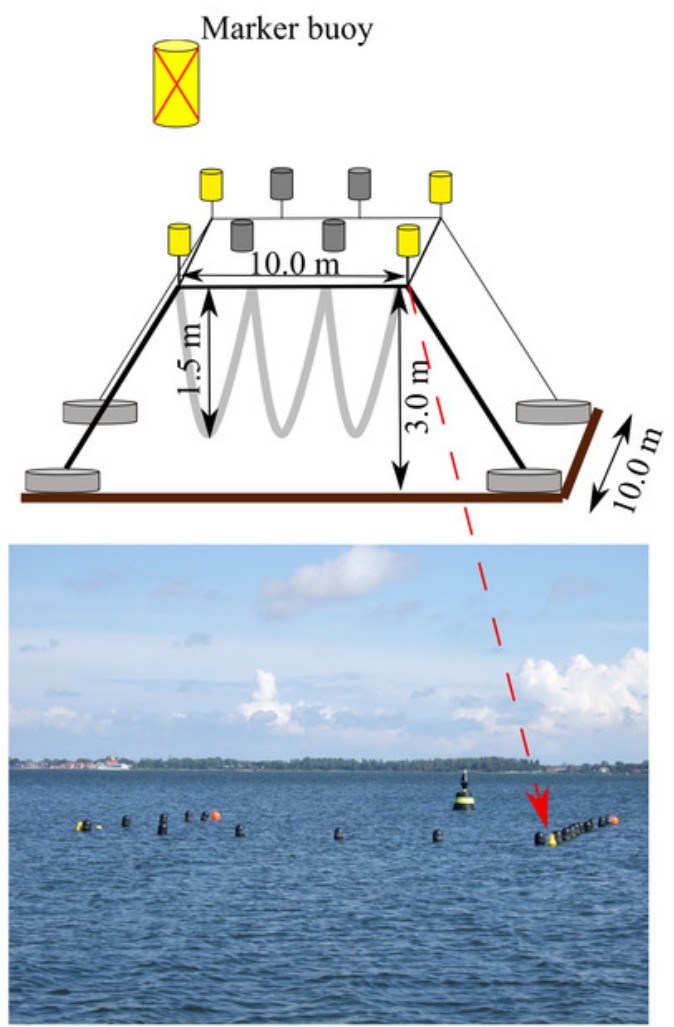


Figure 3

Development of total nutrients, Chl. a concentration and Secchi depth between 1990 and 2018 in the different water bodies of the study site.

Total nitrogen in red, total phosphorus in blue, Chl. a concentration in green and Secchi depth in grey. Deviation between the current status (2020-2018) (spacing and labeled deviation in red) and the target values demanded by the WFD (green lines). 


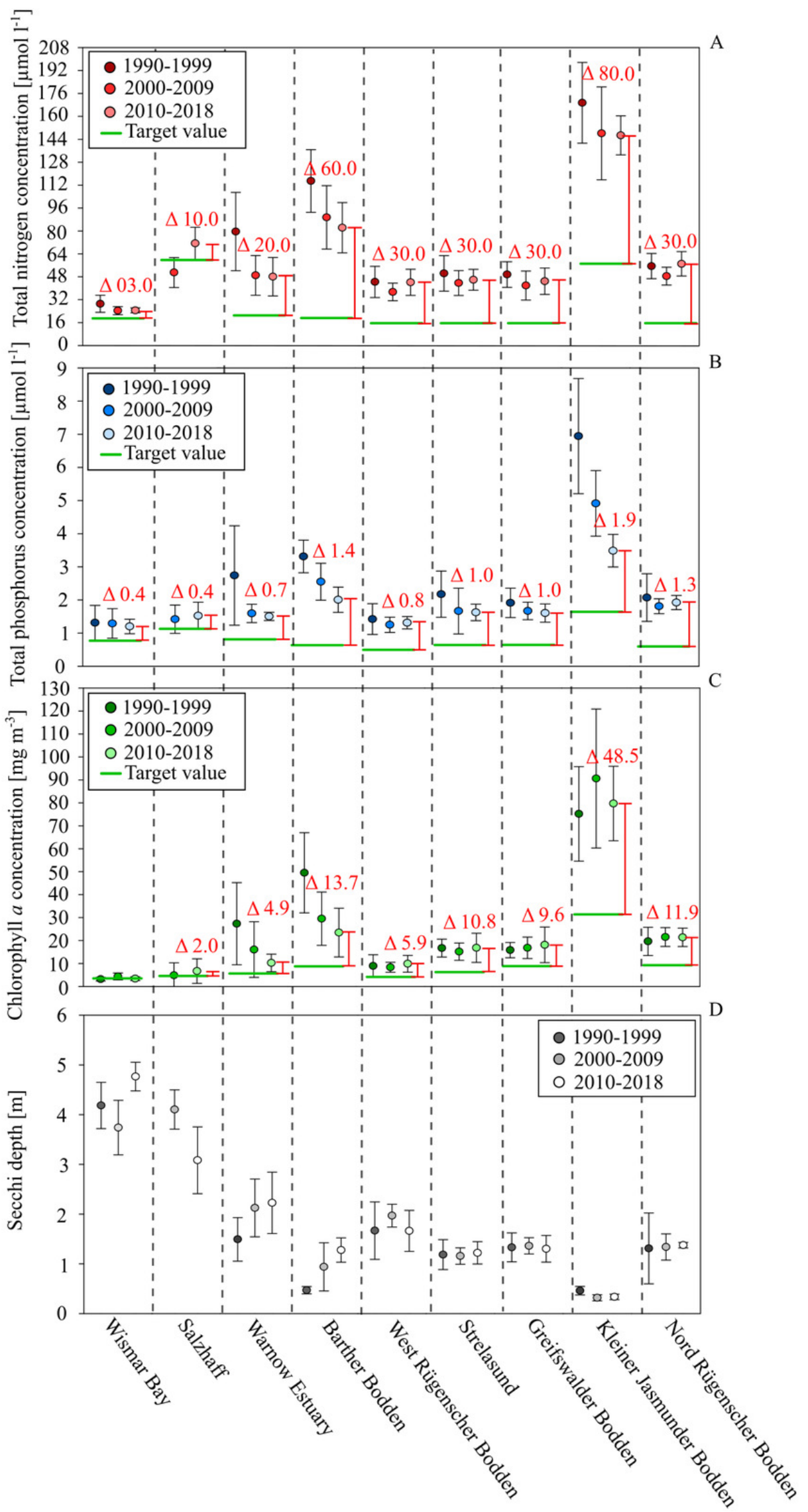


Figure 4

Relationships between total nutrient concentration and Chl. a concentration on a monthly basis in GWB.

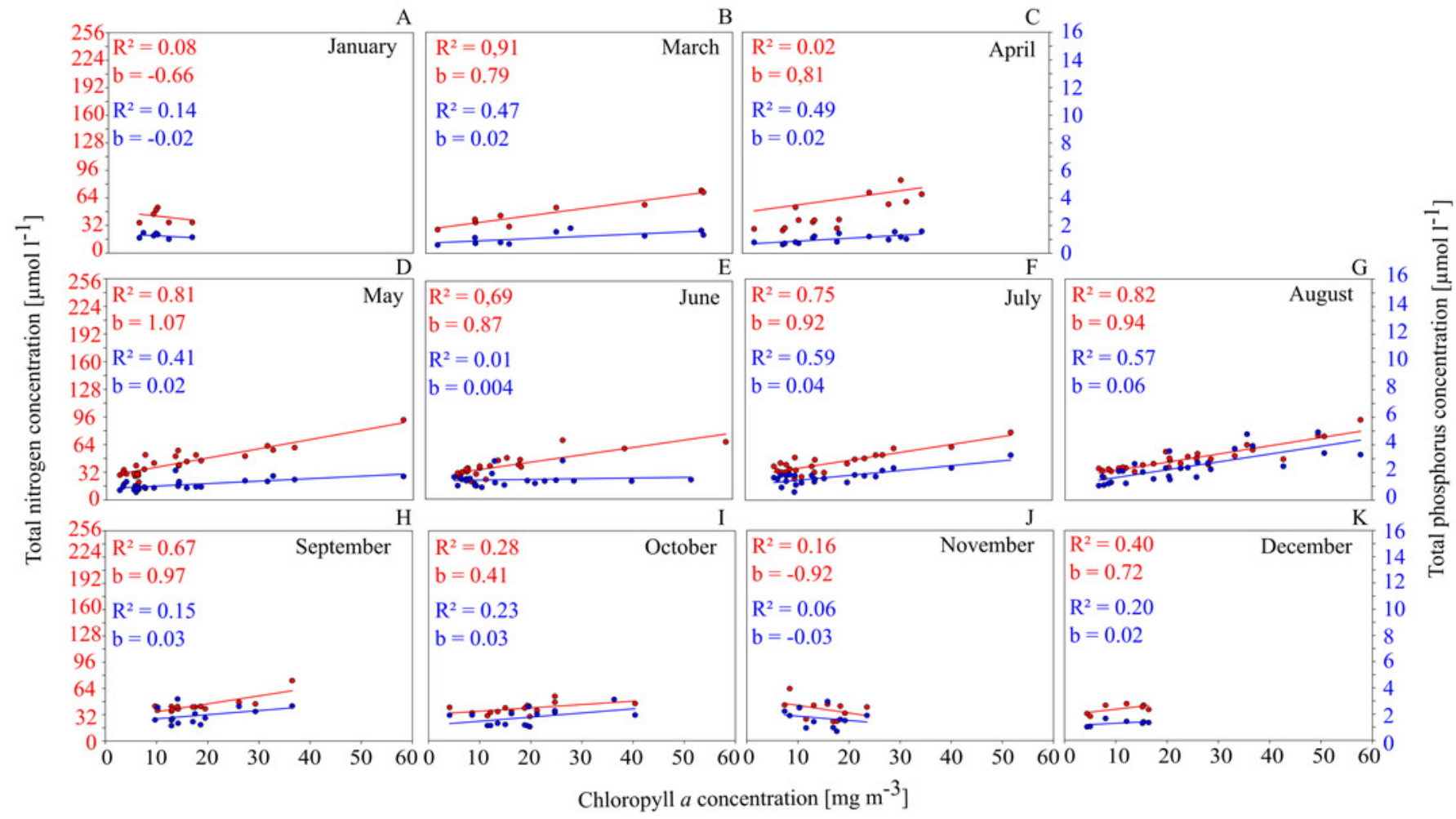




\section{Figure 5}

Linear relationships between $\mathrm{Chl}$. $a$, total nitrogen concentration, total suspended solids and Secchi depth.

(A) Chl. a concentration (Y) as a function of total nitrogen concentration (X). (B) Secchi depth as a function of $\mathrm{Chl}$. a concentration. (C) Secchi depth as a function of total nitrogen concentration. (D) Secchi depth as a function of total suspended solid concentration. Functions are found by single linear regression on logarithmically transformed data $(\ln (Y)=a$ $+b \times \ln (X)$ for the summer months (July-September, 2010-2018) in Greifswald Bay. 

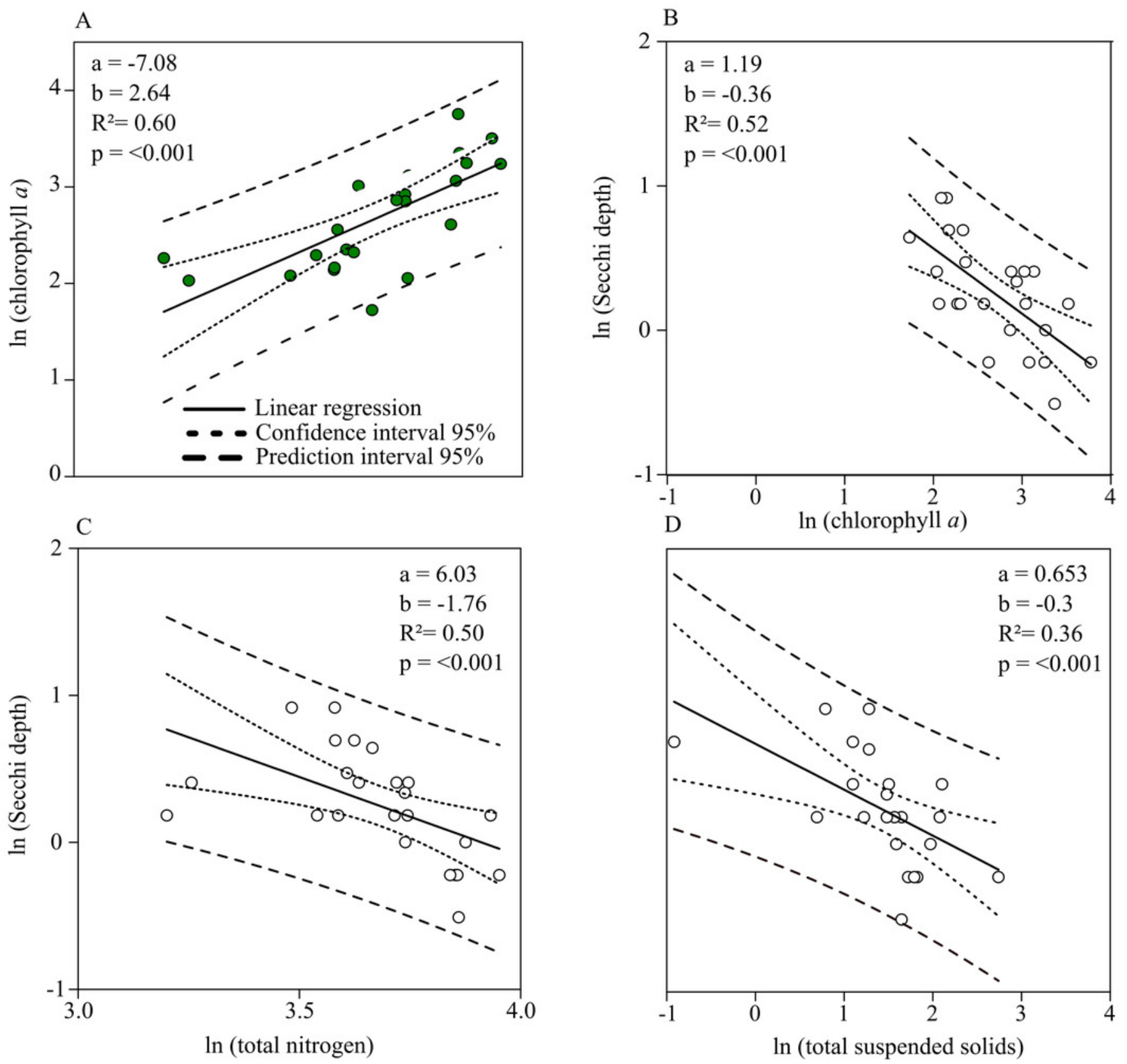
Figure 6

Clearance rates and nutrient content of cultivated blue mussels.

(A) Clearance rates ofMytilus spp. within the pilot farms (pilot farm $1=$ dark green; pilot farm 2 = light green) and under laboratory conditions (white) at different Chl.a concentrations. (B) Total nutrient content in percent of blue mussels

A

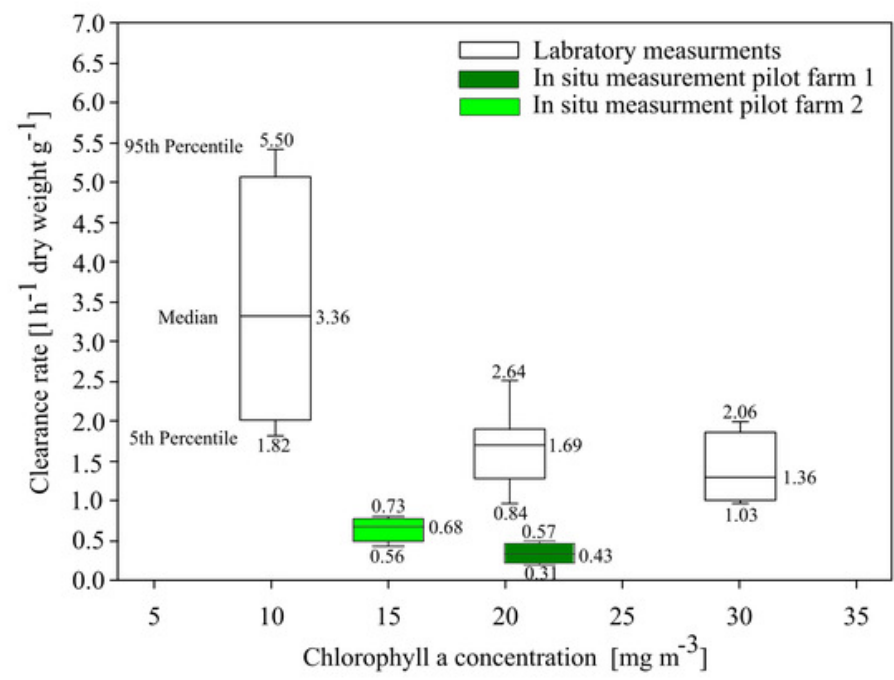

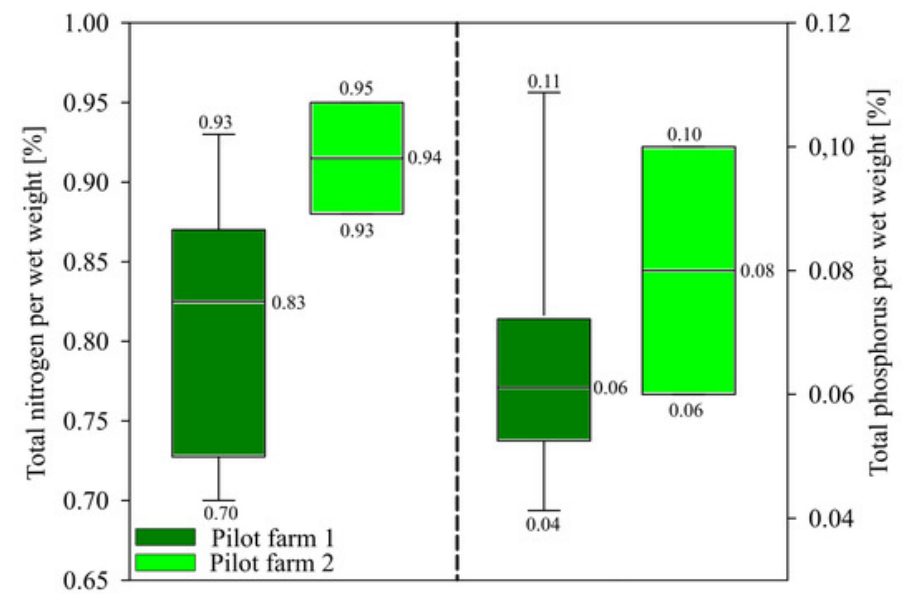


Figure 7

TOC of surface sediment and bio deposition rates within the pilot farm 1.

(A) Surface sediment TOC at the pilot farm 1 (green) compared to reference measurements (white) from 2017 to 2019 divided by seasons and presence of mussel stock. (B) TOC sedimentation rate in the water column in pilot farm 1 (green) and at a reference site (white). For comparison, results from the commercial mussel farm in Kiel are added.

A

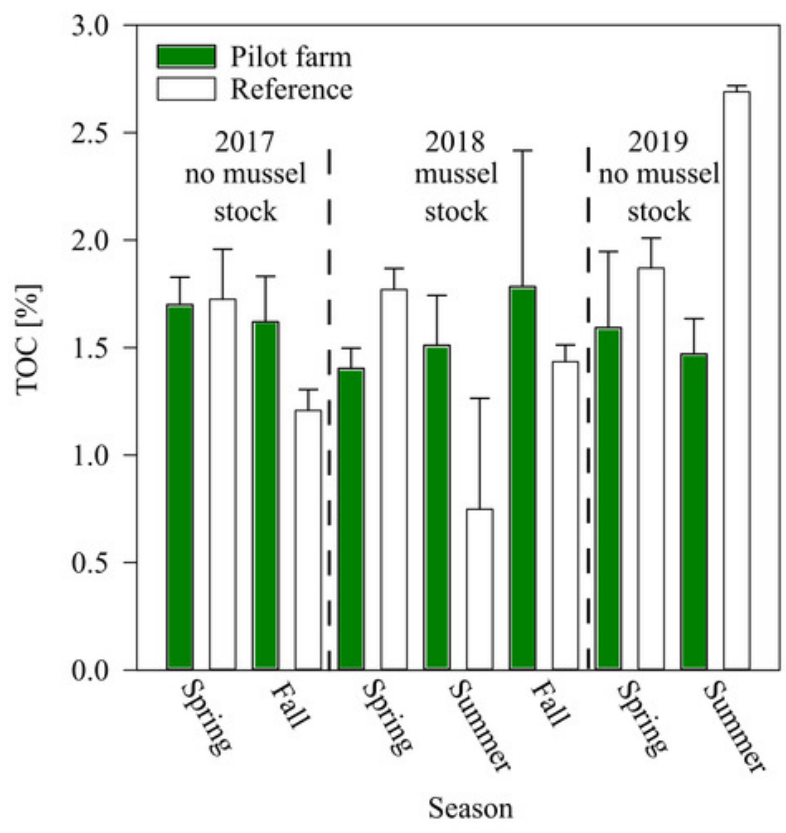

B

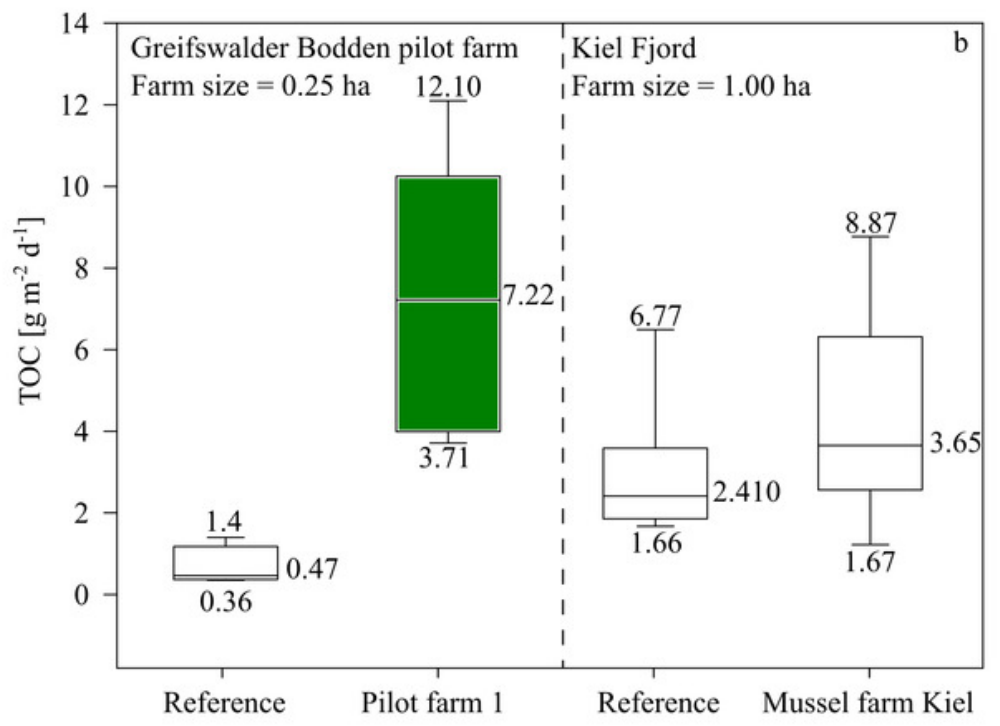




\section{Figure 8}

Vibrio spp. appearance within the pilot farm 1.

(A) Vibrio spp. concentration (CFU $100 \mathrm{ml}^{-1}$ ) at the surface water at the pilot farm 1 compared to a reference measurement. (B) Vibrio spp. concentration (CFU $100 \mathrm{ml}^{-1}$ ) in the water column. Samples were taken via a sediment trap located in the pilot farm and at a reference point. Labeled in red presents the Vibrio spp. concentration (CFU g ${ }^{-1}$ ) detected in the cultivated blue mussels. (C) Vibrio spp. concentration (CFU $100 \mathrm{~g}^{-1}$ ) measured in the surface sediments beneath the pilot farm compared to reference measurement. 


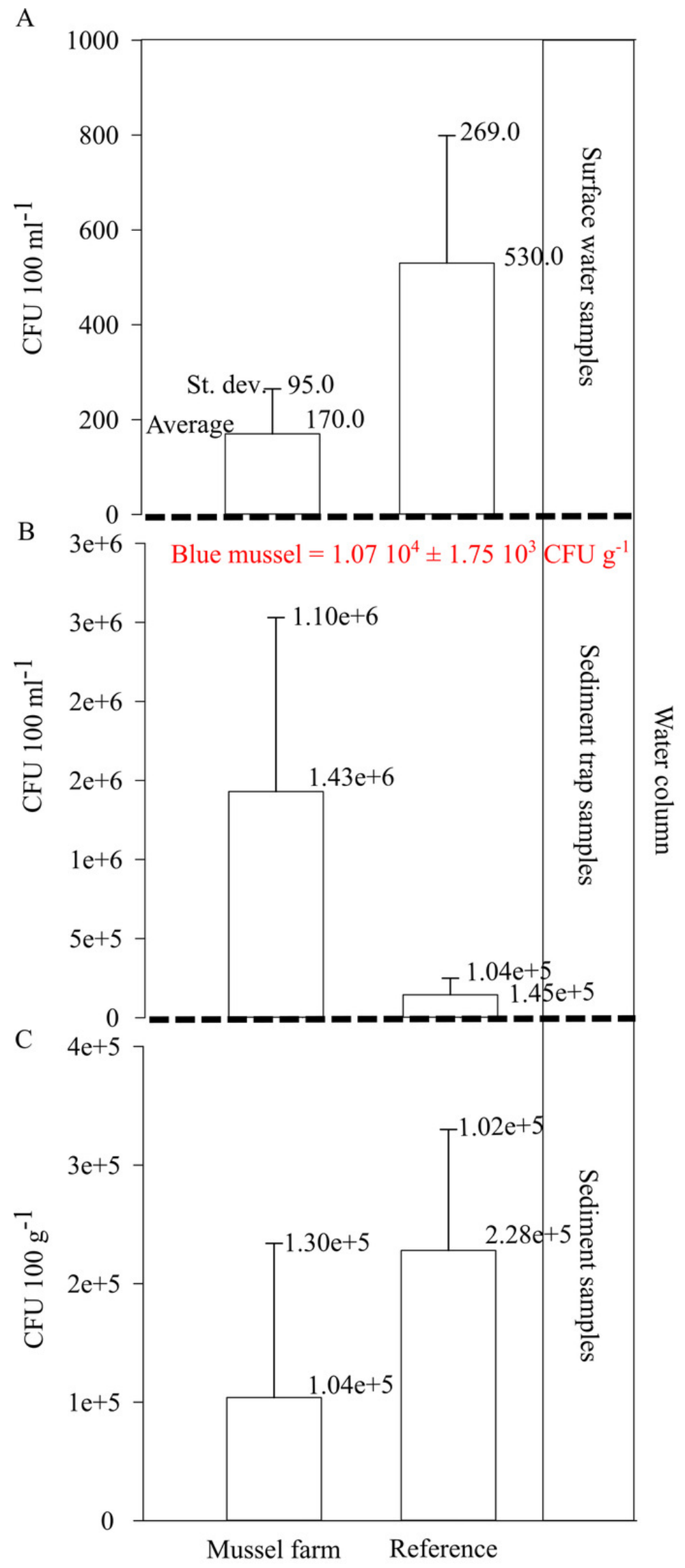




\section{Figure 9}

Annual sales cost assessment for mussel cultivation in GWB and its comparision with reduction costs of land based measures.

(A) Total annual costs per ha mussel farm (red line) and annual sale cost balance for two scenarios (black and black dotted line). Scenario I (black dotted) represents the annual sale cost balance if the mussel farm would generate income by selling feed mussels only. Scenario II represents the annual sales cost balance if the mussel farm generates income by feed mussel sales and nutrient removal derived by removal costs of a WWTP. (B) Nitrogen (red line) and phosphorus (blue line) reduction cost $\left(€ \mathrm{~kg}^{-1}\right)$ per farm size compared to other mitigation measures (dotted box) derived from Gren et al., (2008). 
A

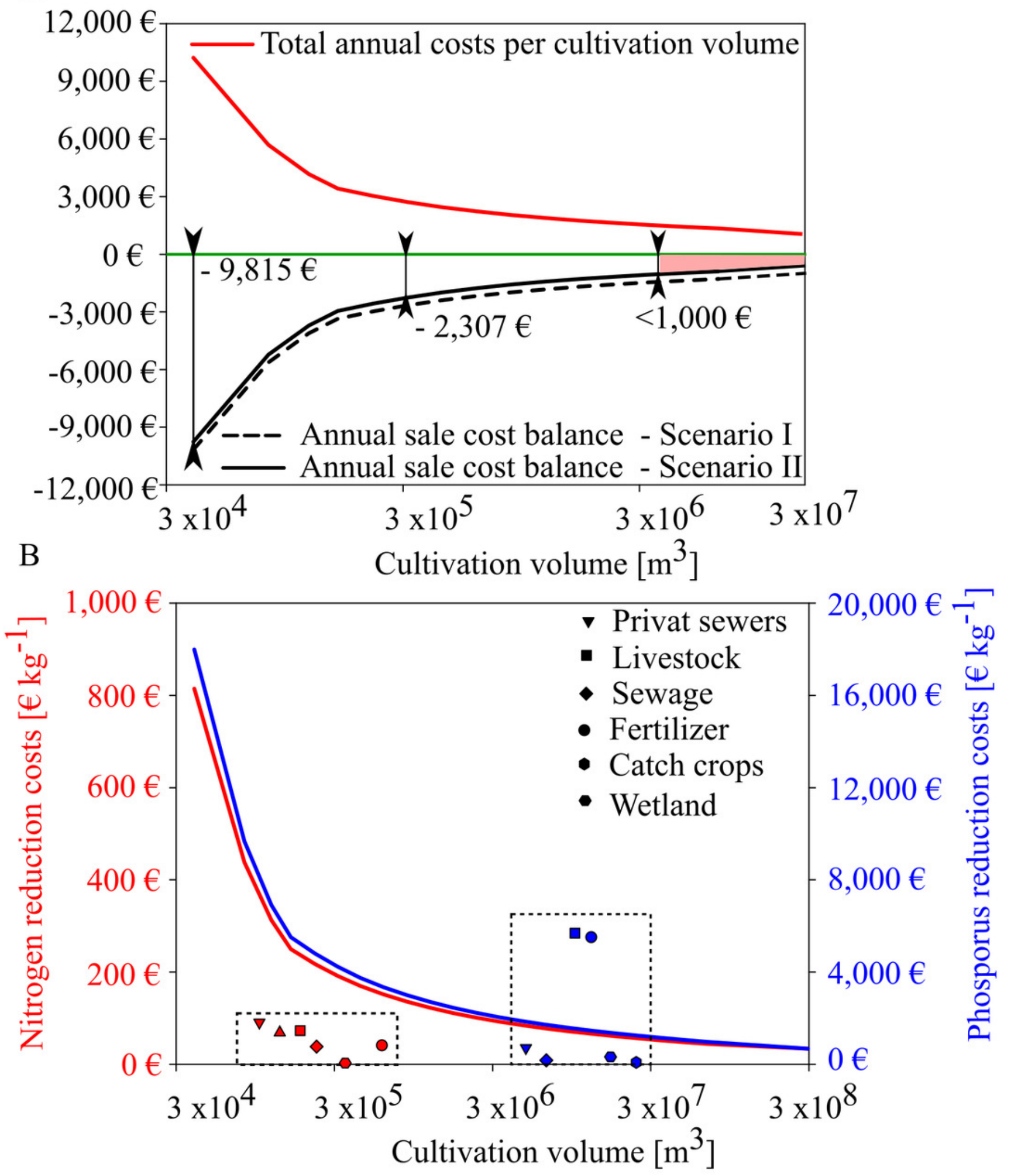

